\title{
Cross-Culture Online Knowledge Validation and the Exclusive Practice of Stem Cell Therapy
}

\author{
Abrar Al-Hasan, Kuwait University, Kuwait \\ iD https://orcid.org/0000-0002-1662-6417 \\ Jiban Khuntia, University of Colorado, Denver, USA \\ Dobin Yim, Loyola University Maryland, USA \\ D https://orcid.org/0000-0002-9360-8343
}

\begin{abstract}
Increasingly, people are turning to the internet to access health information despite reports that sites vary in terms of their quality, especially when the health practice is emerging or exclusive, such as stem cell and umbilical cord blood therapy. Given the controversy, patients have to depend on available sources to validate their knowledge prior to going for these practices as treatments. This study explores how the internet supports the spread of stem cell therapy practices, viewing it from a knowledge validation theoretical perspective. The study posits hypotheses differentiating digital and human sources, trust in the media source, and exploratory and verification sources on knowledge validation for exclusive practices. Primary survey data was collected from the US and Kuwait. Key findings suggest that knowledge verification and trust in the internet influences knowledge conversion and the practice decision of patients for less practice-oriented knowledge, and this effect is higher for Kuwait than USA, and more so for stem cell than umbilical cord blood practice.
\end{abstract}

\section{KEYWORDS}

Culture, Exclusive Practices, Health Information Seeking, Health Information Source, Knowledge Conversion, Knowledge Verification, Stem Cell, Trust

\section{INTRODUCTION}

Deceitful information and advertisements on the Internet for stem cell therapy practices are misleading, with several businesses engaged in direct-to-consumer marketing of non-approved stem cell treatments (Knoepfler \& Turner, 2018). Patients believe and undergo the advertised therapies, resulting in adverse consequences. Examples include three women blinded by unproven treatments (Kuriyan et al., 2017), or halt in the inexorable loss of vision (Mandai et al., 2017), or ending up with new tumors from the treatments (Berkowitz et al., 2016). 
Undoubtedly, the Internet is a significant source that aids in the spread of stem cell therapy practices. However, to what extent the Internet influences the validation of knowledge around stem cell therapies for patients, remains a puzzle equivocally crucial for practice and research. This study tries to unravel this puzzle, viewing it from a knowledge validation theoretical perspective. Knowledge validation is an evaluation process of relevant facts about a medical practice or procedure. It may involve activities that intend to reach the structural correctness of the intended knowledge base (i.e., verification), or activities that intend to show the capability of the knowledge base to reach correct conclusions (i.e., evaluation) (Durcikova \& Gray, 2009). Knowledge validation is essential when the reliability and credibility of the sources are questionable, and lack of access to relevant and truthful knowledge (ter Hoeven, Stohl, Leonardi, \& Stohl, 2019). This is important as the Internet is emerging as the first step information source for health (Daraz et al., 2019) and increasing dependence as an information source (18\% in 2016 to $20 \%$ in 2017) or a primary knowledge avenue (62\% in 2016 to $67 \%$ in 2017) (Gottfried \& Shearer, 2016; Shearer \& Gottfried, 2017).

Extant information systems research has conceptualized that knowledge validation involves a knowledge conversion process, consisting of a series of indirect and direct interactions (Massey \& Montoya-Weiss, 2006). Internet and social media, as channels, are helpful in this process that enables the interactions (Carlson \& Zmud, 1999). Individuals use the interactions to derive useful knowledge from a source, either at a single instance or across time with varied experiences (Massey \& MontoyaWeiss, 2006). Studies also note that irrespective of the knowledge provided by the Internet, trust in such media as a knowledge source and subsequent validation process is a vital puzzle (Daraz et al., 2019; Hou \& Shim, 2010). The credibility of contributed online information is questionable (Archak, Ghose, \& Ipeirotis, 2011; T. Lu, Xu, \& Wallace, 2018), with a push on reality to make the information attractive (Berger \& Milkman, 2012). Most search results are driven by keyword-based matches, ranks of websites, and advertisement potential; and thus, they have built-in biases to provide pushed knowledge than facts (Olteanu, Castillo, Diaz, \& Kiciman, 2019). Although the internet is emerging as the prominent media for a health information source, replacing traditional providers as a source is dubious (Daraz et al., 2019). Whether or not users are able to attain useful knowledge from the Internet that can be translated into a decision to practice the treatment is not yet clear (Grimm et al., 2019; Marsh et al., 2016). Research has also shown the differentiated impact of cultures on the internet search process (Thoumrungroje, 2018; Tian, Deng, Zhang, \& Salmador, 2018). A pertinent question in the context of the Internet as a health information source is does the information provided about practices is useful? If so, to what extent? Do the information search processes translate to valuable knowledge or helpful for knowledge validation? Furthermore, does it lead to a decision to practice the treatment? Do different cultures translate the information search process differently in terms of knowledge conversion of health information?

The study asks the research question: How internet-based knowledge validation and trust influence knowledge conversion, and in turn practice decision, for two exclusive health practices (EHP): stem cell and umbilical cord therapies, in two normative contexts: Kuwait and the United States (US)? EHP are relatively new practices without widespread validated outcomes available to establish the efficacy of the practice, and yet to form a successful and all-embracing clinical guideline to ascertain a practice-to-outcome approach (Ali \& Al-Mulla, 2012; Seay et al., 2017). The stem cell therapy and umbilical cord blood are EHP, that use the regenerative properties of body cells to potentially treat diseases for which currently there are no sustainable cures (Vaquero et al., 2018).

Notwithstanding several plausible clinical trials, there are ethical and policy level controversies with the current evidence of efficacy of stem cell and umbilical cord blood therapies (King \& Perrin, 2014). Stem cell therapy has significant clinical potential, yet, currently, only a few stem cell therapies are ready for actual clinical applications (Guzzo \& O'Sullivan, 2016). This reality has not stopped the rise of clinics worldwide, advertising a wide range of unproven stem cell-based interventions (Dresser, 2010). Many of these clinics have some online presence on the internet and use direct-to-consumer marketing, despite the lack of approval by regulatory organizations (Paarlberg, 2005). 
Given the exaggerated media coverage, and inadequate practice-level information about the two EHP- stem cell and umbilical cord blood therapies, patients have to depend on available sources to validate their knowledge before undergoing the treatments (T. Lu et al., 2018). Thus, it is intriguing whether the type of channel source (digital or offline), trust in the channel source, and the culture impact the knowledge conversion process of gathering, validating information, and practice decision on these therapies - that is the focus of this study. Anchoring to the existing theoretical framework and research on the role of channels and media in the knowledge conversion process, the study posits hypotheses differentiating digital and human sources, trust in the media source, culture, and exploratory and verification sources, on knowledge validation and practice decision for EHP. Primary survey data was collected from the US and Kuwait. Two-stage least squares regression methods are used. Findings suggest that knowledge verification using the internet influences knowledge conversion of patients as compared to offline sources, for less practice-oriented knowledge, and this effect is higher for Kuwait than the US, and more so for stem cell than umbilical cord blood practice (e.g., less EHP). Trust in the source of health information moderates this relationship. In addition, knowledge conversion mediates the relationship on practice decisions.

\section{LITERATURE REVIEW}

EHP originate from clinical trials, these practices are yet to form a successful and all-embracing clinical guideline to ascertain a practice-to-outcome approach (FDA, 2018; Saad, Paoletti, Burzykowski, \& Buyse, 2017). Examples of such practices would be artificial heart, fetal tissue transplantation, gene therapy, and stem cell therapy. New therapies or procedures need to be tested and validated before establishing them as a widespread practice. Because of the significant consequential impact, clinical trials have to follow stringent guidelines and protocols established by regulatory agencies, such as the National Institutes of Health and the FDA (FDA, 2017) making the trials costly and lengthy (Sundberg et al., 2017).

Cost and time factors lead researchers to often release the interim results of trials through publications or reports than waiting for completely validated and established results that apply to a broader population (Sundberg et al., 2017). Such interpretations lead to EHP that are not validated yet practiced using the limited information and interpretation coming out of ongoing clinical trials (Glasgow, 2005).

These practices need to be followed with caution. Nevertheless, some of these results are adopted by opportunistic practitioners and clinicians, with dubious effects to earn money (Murdoch, Zarzeczny, $\&$ Caulfield, 2018). Patients are attracted by false advertisements to avail of these practices (Murdoch et al., 2018; von Tigerstrom, 2017). Whether patients rely on the internet or other sources to verify the efficacy of these falsely advertised EHP potentials, remains a wide gap for healthcare practice and academics equivocally.

Stem cell and umbilical cord therapies are EHP that use regenerative properties of human body cells, to produce both copies of themselves and more specialized cells for potential adult therapeutic applications (Vaquero et al., 2018). Early growth of the commercial market for unproven stem cellbased started from Asia and is currently spreading worldwide. Governing stem cell therapies is still at its infancy (Cossu et al., 2018; George, 2011). Although international efforts to regulate stem cell practices are emerging, however, these guidelines are not yet conclusive (Murdoch et al., 2018).

Until more international standardization has occurred, the focus for online and health information systems in the realm of new technologies such as stem cell therapy should probably be on filtering and consolidation of accurate information to patients. An online search for stem cell practice using Google reveals unreliable information, mainly driven by advertisements (Murdoch et al., 2018). Thus, online information on stem cell practices may be confusing and overwhelming. Interpretation of the information may lead to invalidated applications of the information presented. Therefore, the issue examined in this study, how far information on the Internet can be used to validate patients' knowledge 
compared to offline knowledge is a valid concern. Also, comparative evidence of such effect across different cultural settings although a difficult task, no doubt, but an important one.

\section{Hypotheses}

Conceptually, this study argues that online sources have a significant impact on validating and deciding to take on the EHP - the stem cell and umbilical cord practices. Furthermore, the study also argues for the crucial role of trust in the source of information and the importance of the culture as a differentiating factor. The theoretical underpinning for this validation is posited to be the existing discussions around the knowledge conversion process (Massey \& Montoya-Weiss, 2006), media

Figure 1. Research model

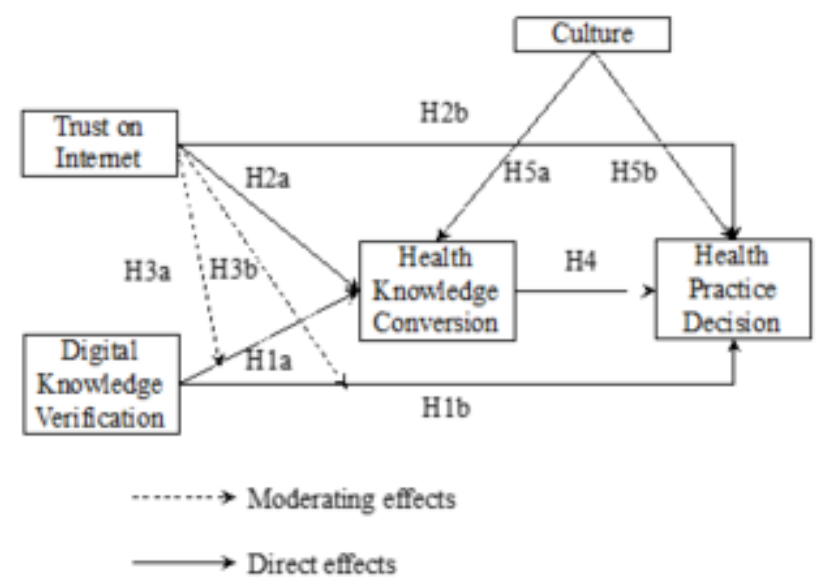

richness theory (Carlson \& Zmud, 1999), and trust in the information source (Sillence, Briggs, Harris, \& Fishwick, 2007). The research model is shown in Figure 1 and the theoretical arguments are further explained to posit testable hypotheses.

Knowledge conversion is the process by which individuals are affected by the experience of another, which may be embodied in the mind of another or a knowledge artifact (Argote et al., 2003; Massey \& Montoya-Weiss, 2006; Paulin \& Suneson, 2015). Knowledge artifacts are intermediary mechanisms used to capture and provide experience to others. The success of knowledge conversion hinges on both developing understanding, and the ability to use knowledge in some local context (Åkerman, 2015; Casillas, Barbero, \& Sapienza, 2015). Knowledge conversion process occurs through a sequence of interactions over time that takes two forms: (1) indirect knowledge conversion: independent interaction by individuals with a knowledge artifact, and (2) direct knowledge conversion: communication between participants and may be complemented by using knowledge artifacts (Massey \& Montoya-Weiss, 2006).

Media richness theory (MRT) suggests that communication media differs in their ability to facilitate understanding of information cues and reduce uncertainties (Daft \& Lengel, 1986; Suh, 1999). MRT suggests that individuals' learning is a function of the characteristics of the channel (i.e., media richness) and the learning task (i.e., uncertainty). Media richness refers to a channel's ability to transfer information, that is determined by its capacity for immediate feedback, the multiple cues and senses involved, language variety, and personalization (Lengel \& Daft, 1988). The richness of media or the utility of the media characterizes a channel's ability to communicate multiple information and promote personal decision-making within that channel (Maity \& Dass, 2014). MRT suggests that the 
more ambiguous the task, the more complex the channel needs to be for successful communication (Kock, 2005). Each information channel possesses inherent characteristics that comprise its richness and utility; however, individual experience, perceived usefulness, and ease of use also influence the richness factor (Anandarajan, Zaman, Dai, \& Arinze, 2010). Furthermore, richness and utility are influenced by socially constructed knowledge through learning from others (Liu, Tan, \& Sutanto, 2018).

Existing literature has shown that the higher media utility and richness, the easier it is to convey information, thus facilitating better communication, learning and decision making because the information receiver can rapidly and correctly understand the other party (Tseng, Cheng, Li, \& Teng, 2017). With the advancement of digital content, health information online is always available for users, the information is always updated, even customized, and users are able to attain immediate feedback online (Huo, Zhang, \& Ma, 2018). On the other hand, physicians and offline channels of health information such as books, family and friends are not always available and have limited time. Furthermore, with the development of communication technology, there are many ways to share information (Lozoya et al., 2018). Information is presented digitally in many ways through pictures, videos, specialized applications, personalized notification, among others. Therefore, digital health information which is richer in content and represented with multiple patterns might leave people clearer perceptions and deeper impressions than the health knowledge from official offline channels that are not as rich (Lipowski \& Bondos, 2018; Nisar, Prabhakar, \& Strakova, 2019) . Therefore, health knowledge conveyed offline as compared to digital knowledge potentially has lower media richness (Huo et al., 2018). Furthermore, the richer the media, the deeper the resulting cognition and understanding, and the more precise the perception of knowledge quality becomes. The richness and perceived utility of the media and intellectual capital affects the knowledge conversion process (Attar, Kang, \& Sohaib, 2019; Massey \& Montoya-Weiss, 2006; van Woerkom \& Sanders, 2010).

With the exaggerated media coverage and insufficient practice-level information on EHP, users have to depend on available information sources to validate their knowledge before deciding to partake in such treatments. Knowledge validation is an evaluation and verification process of relevant facts about a medical practice or procedure. It may involve activities that intend to reach the structural correctness of the intended knowledge base (i.e., verification), or activities that anticipate demonstrating the ability of the knowledge base to conclude properly (i.e., evaluation) (Durcikova $\&$ Gray, 2009). Knowledge validation is essential when the reliability and credibility of the sources are questionable, and when there is a lack of access to relevant and truthful knowledge (ter Hoeven et al., 2019) - such as EHP. Knowledge verification of digital media allows for both indirect and direct knowledge conversion. Indirect knowledge conversion through reading online health information, and direct knowledge conversion by the ability to communicate with health professionals online.

Based on the above discussion, this study argues that digital media provides richer health content that will translate to higher knowledge quality and conversion, and ultimately deciding on partaking the treatment. Thus, we hypothesize:

Hypothesis 1a: Digital Media based knowledge verification is positively associated with health knowledge conversion.

Hypothesis 1b: Digital Media based knowledge verification is positively associated with practice decision.

With higher exclusivity of the practice, there may be fewer opportunities to attain information. Knowledge seekers and sources may hit a wall to validate or converse. Out of stem cell and umbilical practices, the exclusivity of knowledge may differ, thus, the study expects that that the impact of knowledge validation on knowledge conversion may differ-however, prediction of a degree of which is difficult, without measuring the exclusivity intensity of these practices. Thus, the study explores how the knowledge validation to conversation relationship differs across these practices, without stating any specific hypothesis. 
Studies have suggested that the Internet is the main source of information, especially when the information is about sensitive illnesses (M. Berger, Wagner, \& Baker, 2005; Klein \& Wilson, 2002). Individuals trust online sources for health information and advice (Sillence et al., 2007). However, this trust may be misplaced. Several recent studies have evaluated the content of health websites and have concluded that the quality of health information is poor (Arif \& Ghezzi, 2018; Daraz et al., 2019; Ernst et al., 2019).

The MRT suggests that media channel perceptions are developed based on different user experiences (Carlson \& Zmud, 1999). Through the knowledge conversion process, individual and shared experiences affect the perceived utility of media (Massey \& Montoya-Weiss, 2006). Using the Internet for health-related purposes may be informative as users find relevant information. Yet, for others, seeking health information online may be confusing, and overwhelming (Jiang \& Beaudoin, 2016). With such negative Internet experience, the impact of online health information seeking on perceived health information might be weakened (Kim, Lustria, Burke, \& Kwon, 2007). In contrast, positive Internet experiences increase the ability to take advantage of the resources found online (Chang \& Chen, 2008). For example, when online users seek predominant health information, less difficulty is encountered in processing health information (Josefsson, 2006). However, when the information is more exclusive and difficult to find, the perceived health information might be weakened (Qiu et al., 2017). Information overload on the Internet and limited attention contribute to the degradation of the Internet experience (Qiu et al., 2017). Therefore, the more a user trusts the Internet as a source, the more positive a user's experience will be, and thus, the more knowledge the user will gain (Gefen, Karahanna, \& Straub, 2003) and the higher the intention to transact (McKnight, Choudhury, \& Kacmar, 2002). MRT suggests that the more ambiguous the task, the more complex the channel needs to be for successful learning (Kock, 2005). Therefore, the richer media- or digital media- is utilized for ambiguous tasks (Nisar et al., 2019) such as information on EHP. Extending the focus beyond information seeking to seek exclusive health information on the Internet, the study expects to observe a similar pattern of association between trust in online sources and knowledge conversion and in turn, practice decision. Thus:

Hypothesis 2a: Individual's trust in the digital medium drives them to leverage from digital sources for knowledge conversion.

Hypothesis 2b: Individual's trust in the-digital medium drives them to leverage from digital sources for practice decisions.

The infinite amount of information offered by the Internet makes searching for information on usually time-consuming and thus reducing the media utility of the channel (Eysenbach \& Jadad, 2001). Internet users frequently experience confusion caused by the mass amount of poorly organized information available with variable quality and relevance (Eysenbach \& Jadad, 2001; Qiu et al., 2017). Also, health information online has been produced at a higher reading level than the estimated average reading level of an average patient (Meghan, Paul, Hussein, Cross, \& Della Valle, 2017). Expectedly patients will experience even more confusion, trying to find and comprehend the intended information (Swar, Hameed, \& Reychav, 2017). With higher exclusivity of the practice, it may be even more confusing and more difficult to find and process the information. Therefore, the degree of exclusivity might differ in the relationship between trust and knowledge conversion. Again, how trust in the Internet and knowledge conversion relationship differs across the two EHP: stem cells and umbilical cord blood is explored, without stating any specific hypothesis. Nevertheless, the interaction of trust in the Internet and knowledge verification should influence the knowledge conversion and in turn, practice decision.

Access to reliable information is linked to reduced anxiety and trust (Sohaib \& Kang, 2017). Studies have shown that educating patients with reliable information is effective in preventing and reducing anxiety (Garcia, 2014). While the Internet may cause information overload anxiety (Reinecke 
et al., 2017; Swar et al., 2017), it can also lead to reduced anxiety when the information is reliable and understandable (Alnafea, Fedele, Porter, \& Ni Riordain, 2017). In line with MRT, when a user trusts the Internet the user will be able to attain a better experience and a more reliable and understandable experience (Sbaffi \& Rowley, 2017) as well as the decision to conduct a transaction (Sohaib, Kang, \& Nurunnabi, 2019). Following through with MRT, studies have shown that when a user trusts the media channel, the user will gain more knowledge as compared to when the user has had a bad experience with the channel (Lipowski \& Bondos, 2018; Tseng et al., 2017). Therefore, the study hypothesizes that the more a user trusts the digital source, the more knowledge will be validated and thus the higher the knowledge converted.

Hypothesis 3a: Trust moderates the relationship between digital media, knowledge verification, and their impact on knowledge conversion.

Hypothesis 3b: Trust moderates the relationship between digital media, knowledge verification, and their impact on practice decisions.

Patient choices need to be based on good information. The more knowledge a patient has, the more confident the patient will be in making an informative decision (Frieden, 2017). Decisionmaking on health treatments should be guided by informative knowledge (Nguyen, Mosadeghi, \& Almario, 2017). According to MRT users will receive more information through richer media, and this information tends to be easier to interpret, assimilate, and involves lower cognitive costs (Maity, Dass, \& Kumar, 2018). The Knowledge-to-Action framework (Graham et al., 2006) emphasizes crucial steps toward selecting and implementing health interventions and decisions (Gagné \& Boulet, 2018). The framework is composed of two main components (1) Knowledge creation and (2) Action. Various studies in the health care field (Bjørk et al., 2013; Hua et al., 2012; Stacey et al., 2009) have shown the importance of knowledge creation before taking action. Thus, the study hypothesizes that knowledge conversion is a mediator for the relationship between knowledge verification, trust, and their impact on practice decisions.

Hypothesis 4: The impact of knowledge verification and trust on practice decision is mediated by knowledge conversion.

The US and Kuwait have different cultural contexts. National culture is a collective mindset that distinguishes members of one nation from another, differentiated by value dimensions such as individualism, power distance, and uncertainty avoidance - that are relevant to the context of knowledge exploration and validations concepts used in this study (Hofstede, 2003; Triandis, 2018). Extant research has used the value dimensions to explain the use of the Internet for knowledge seeking significantly improves across time (Lane, Khuntia, Parthasarathy, \& Hazarika, 2017). Prior research has alluded to these factors to explore the usage of technology and digital media to impact communication and coordination (de Mooij, 2017; Gonzalez-Loureiro, Sousa, \& Pinto, 2017; Thoumrungroje, 2018), website design and trust among various cultures (Cyr, 2013), and in uncertainty avoidance (Sohaib, Kang, \& Miliszewska, 2019).

This study argues that individuals in Kuwait and the US, driven by individual values, will leverage differently from the knowledge validation to the conversion process using the Internet. For instance, Kuwait is reflected as a collectivistic value-driven culture with Hofstede Individualism score of 25, whereas the US has a 91 score. Individualism refers to the degree of interdependence, and lower scores reflect that ties between people are strong. Being collective denotes that individuals in Kuwait are integrated into strong cohesive groups, with loyalty and commitments to the group. Individuals in collective cultures will base their self-understanding on the reactions of others around them (Triandis, 2018; Yun, Mohan, \& Zhao, 2017), in contrast to people in the US who will base 
their self-understanding on their own independent actions regardless of what others think (Triandis, 2018; Zeffane, 2017).

Based on collectivistic culture, Kuwaiti Internet users are more likely to learn from online verification because they believe that such information is more likely to be associated with their societal pre-existing beliefs (Lucas, 2006). Individualistic cultures search for new information rather than verify the information at hand (Bhagat, Kedia, Harveston, \& Triandis, 2002). Furthermore, collectivistic societies are more influenced by media as compared to individualistic societies (Singh, 2006). This is even more fitting when the type of knowledge is novel and exclusive. This arguably is the rationale to expect that individuals in Kuwait will have a stronger validation process of knowledge conversion in the stem cell and umbilical cord blood practice as compared to individuals in the US.

In a similar vein, Kuwait scores high in power distance trait, as compared to the US (score of 90 versus 40). Power distance in a given society indicates the differences in the intellectual spread of people. Cultures with large power distance tend to be hierarchical, while those with small power distance tend to value equality. In low power distance cultures where equality and independence are highly valued, people depend less on others and are more likely to use commercial sources for information (Stump \& Gong, 2017). In contrast, in high power distance cultures, people rely on personal sources of recommendation and favor peer interaction rather than commercial sources (Stump \& Gong, 2017). Consumers in larger power distance cultures will display a higher propensity to be influenced by digital media and communications than those in smaller power distance cultures (Singh, 2006). Expectedly, in cultures with high power distance, people will be more influenced by the information they are provided, and thus their validation process of knowledge conversion will be higher than cultures with low power distance.

Uncertainty avoidance reflects on the ambiguous situations in a culture. Societies feel endangered by these situations, and thus, create principles that try to avoid these. A high score means the society prefers to avoid uncertainty, and a low score means the society tolerates ambiguity. Kuwait scores 80 on this dimension (versus 46 for the US) and thus prefers avoiding uncertainty. Kuwait is a culture that is highly intolerant of ambiguity, and to minimize the anxiety associated with the uncertainty, the society will exploit knowledge to confirm information.

Kuwait is a collectivist society with higher power distance and uncertainty avoidance traits than the US. Given the differences between the two cultures, the study expects that the impact of knowledge validation and trust on knowledge conversion and practice decisions may differ. In particular:

Hypothesis 5a: Users residing in Kuwait will have a higher knowledge conversion impact than users residing in the US.

Hypothesis 5b: Users residing in Kuwait will have a higher practice decision impact than users residing in the US.

\section{RESEARCH METHODS}

The dataset comes from primary survey data, which was developed and tested on two distinct populations, Kuwait and the US. These two countries are exemplars of collectivist and individualistic cultures, respectively in 2017. Offline and online surveys were conducted. A pilot-test was conducted on a sample of 18 in Kuwait and the US for both offline and online surveys. The refinement process was minor and mainly focused on the wording of the items. The final survey questionnaire is provided in Table 1.

The survey in Kuwait was conducted over two months from May 2017 to July 2017, and the sample is composed of 506 responses. The survey in the US was conducted over 2 months from October 2017 to December 2017 and the sample is composed of 215 responses. The survey items were based on existing validated scales. Around $63 \%$ of the overall sample were female (Appendix displays detailed descriptive statistics on the respondent's demographics and characteristics). While only $1 \%$ of the 
Table 1. Description of variables

\begin{tabular}{|c|c|}
\hline Variable & Description \\
\hline \multicolumn{2}{|r|}{ Dependent Variables } \\
\hline PD_UMB & $\begin{array}{l}\text { Practice decision to undergo a treatment using umbilical cord blood therapy. } \\
\text { Question: Would you store the cord blood of your newborn? Yes_, No__, Not sure_.. } \\
\text { The variable was coded as } 1 \text { if the response is Yes, and } 0 \text { otherwise. }\end{array}$ \\
\hline PD_STEM & $\begin{array}{l}\text { Practice decision to undergo a treatment using stem cell therapy. } \\
\text { Question: Have you visited websites of centers offering stem cell therapies? Yes_, No__. } \\
\text { The variable was coded as } 1 \text { if the response is Yes, and } 0 \text { otherwise. }\end{array}$ \\
\hline KC_STEM & 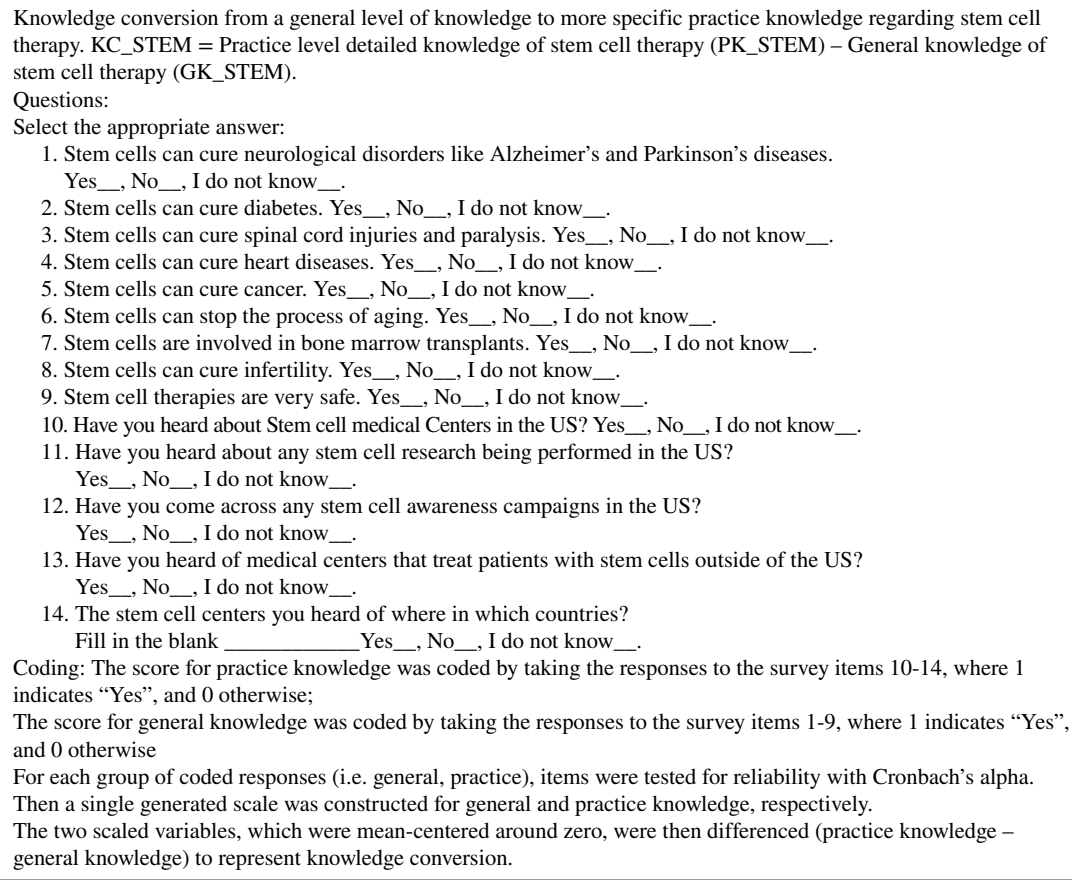 \\
\hline KC_UMB & 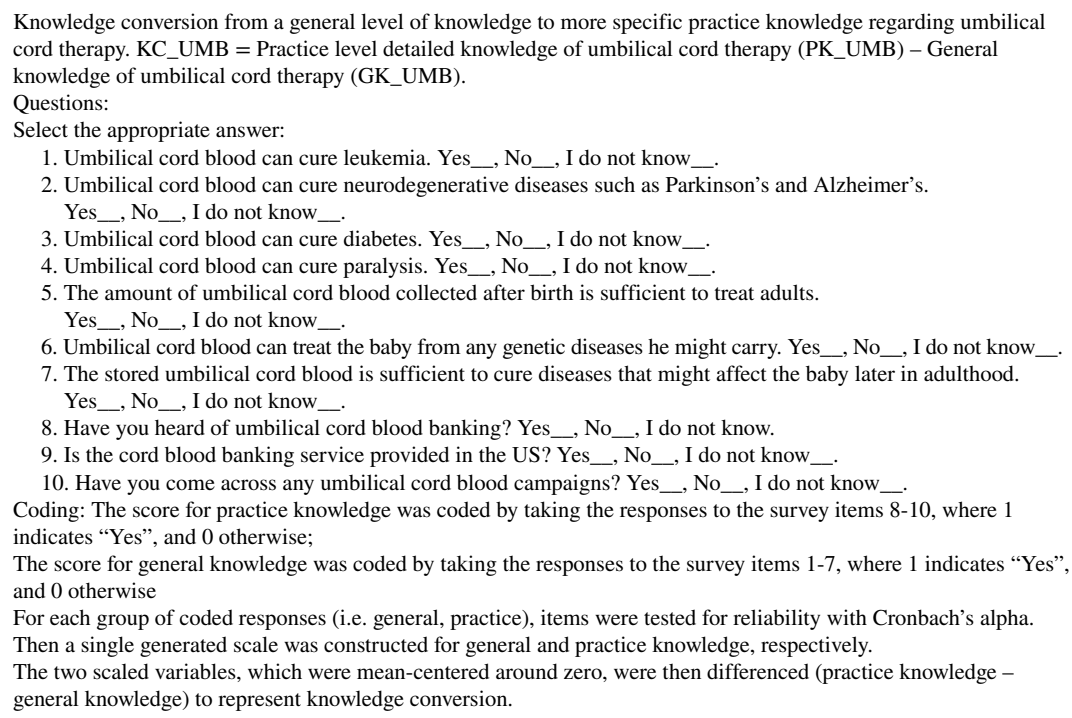 \\
\hline
\end{tabular}


Table 1. Continued

\begin{tabular}{|c|c|}
\hline Variable & Description \\
\hline \multicolumn{2}{|r|}{ Independent Variables } \\
\hline DIGITAL_VER & $\begin{array}{l}\text { Digital media-based knowledge verification. Confirmatory verification of knowledge using digital sources (e.g., } \\
\text { internet and social media) for a health condition or disease. } \\
\text { Questions: } \\
\text { After seeing a doctor I also check the following for more information (Choose all that apply): Internet websites__, } \\
\text { Social Media (Twitter, Facebook, Instagram, etc.)_, Books_, Friends and family (non-specialists)_, None__. } \\
\text { Coding: The design variables (i.e. eight-items checklist) were transformed into seven dummy variables, where } \\
\text { checked responses to each item were coded as } 1 \text {, or } 0 \text { otherwise. Factor analysis was then conducted, and a factor } \\
\text { with high loading scores on "Internet Website" and "Social Media" was chosen to represent digital media-based } \\
\text { knowledge verification. }\end{array}$ \\
\hline DIGITAL_TRUST & $\begin{array}{l}\text { Trust in the digital media (e.g., internet and social media) for public health information. } \\
\text { Questions: } \\
\text { From a scale of 1-5 (1: Strongly Disagree; 2: Disagree; 3: Neither Agree nor Disagree; 4: Agree; 5: Strongly Agree), } \\
\text { please answer the following: } \\
\text { 1. In general, most people can be trusted. } \\
\text { 2. In general, I am very careful dealing with people. } \\
\text { 3. In general, most people try to be fair. } \\
\text { 4. Most people in the healthcare system will try to take advantage of you if they get a chance. } \\
\text { 5. I am confident in hospital doctors. } \\
\text { 6. I am confident in the health information I find on the internet. } \\
\text { 7. I believe that the doctors' interest is in the care of the patient above the interest of his own financial benefit. } \\
\text { The items were tested for reliability with Cronbach's alpha, and then a single variable with mean-centered and } \\
\text { standardized values was constructed. }\end{array}$ \\
\hline \multicolumn{2}{|r|}{ Variables Used as Controls and for Additional Analyses } \\
\hline DIGITAL_EVL & $\begin{array}{l}\text { Digital media-based knowledge evaluation. The extent to which digital media was used as an exploratory search } \\
\text { about a health condition or disease. } \\
\text { Questions: } \\
\text { Before seeing a doctor I check the following for more information (Choose all that apply): Internet websites_, Social } \\
\text { Media (Twitter, Facebook, Instagram, etc.)_, Books_, Friends and family (non-specialists)_, None__. } \\
\text { Coding: The design variables (i.e. eight-items checklist) were transformed into seven dummy variables, where } \\
\text { checked responses to each item were coded as } 1 \text {, or } 0 \text { otherwise. Factor analysis was then conducted, and a factor } \\
\text { with high loading scores on "Internet Website" and "Social Media" was chosen to represent digital media-based } \\
\text { knowledge evaluation. }\end{array}$ \\
\hline DIGITAL & $\begin{array}{l}\text { Use of digital media sources (e.g., internet and social media) as a health information source. } \\
\text { Questions: } \\
\text { 1- In general, your primary source of health and medical information is: Internet websites_, Doctors and } \\
\text { Specialists_, Friends and family (non-specialists), Books_, TV__, Newspapers and magazines_, Social } \\
\text { media(Twitter, Facebook, Instagram, etc.)__. } \\
\text { 2- If you had a health-related question, whom would you ask first? Internet websites_, Doctors and Specialists_, } \\
\text { Friends and family (non-specialists), Books_, TV__, Newspapers and magazines_, Social media (Twitter, } \\
\text { Facebook, Instagram, etc.)_. } \\
\text { Coding: The variable was coded by taking the responses to the following survey items 1-2. "Internet websites" and } \\
\text { "Social Media" were coded as } 1 \text {, and } 0 \text { otherwise. The two items were tested for reliability with Cronbach's alpha, } \\
\text { and then a single generated scale was constructed. }\end{array}$ \\
\hline HUMAN_EVL & $\begin{array}{l}\text { Human-based knowledge evaluation. The extent to which human source was used as an exploratory search about a } \\
\text { health condition or disease. } \\
\text { Question: Before seeing a doctor I check the following for more information (Choose all that apply): Internet websites_, } \\
\text { Social Media (Twitter, Facebook, Instagram, etc.)_, Books_, Friends and family (non-specialists)_, None__. } \\
\text { Coding: The design variables (i.e. eight-items checklist) were transformed into seven dummy variables, where } \\
\text { checked responses to each item were coded as 1, or } 0 \text { otherwise. Factor analysis was then conducted, and a factor } \\
\text { with high loading scores on "Friends and Family" was chosen to represent human knowledge evaluation. }\end{array}$ \\
\hline HUMAN_VER & $\begin{array}{l}\text { Human-based knowledge verification. Confirmatory verification of knowledge using human sources (e.g., doctor, } \\
\text { friends, and family) for health condition or disease. } \\
\text { Question: After seeing a doctor I also check the following for more information (Choose all that apply): Internet websites__, } \\
\text { Social Media (Twitter, Facebook, Instagram, etc.)_, Books_, Friends and family (non-specialists)_, None__. } \\
\text { Coding: The design variables (i.e. eight-items checklist) were transformed into seven dummy variables, where } \\
\text { checked responses to each item were coded as 1, or } 0 \text { otherwise. Factor analysis was then conducted, and a factor } \\
\text { with high loading scores on "Friends and Family" was chosen to represent human knowledge verification. }\end{array}$ \\
\hline CULTURE & Place of residence, Kuwait $($ Culture $=1)$ or US $($ Culture $=0)$. \\
\hline
\end{tabular}


Table 1. Continued

\begin{tabular}{|c|c|}
\hline Variable & Description \\
\hline DOCTOR & $\begin{array}{l}\text { Use of doctor as a source of health information. } \\
\text { Questions: } \\
\text { 1- In general, your primary source of health and medical information is: Internet websites_, Doctors and } \\
\text { Specialists_, Friends and family (non-specialists), Books_, TV__, Newspapers and magazines_, Social } \\
\text { media(Twitter, Facebook, Instagram, etc.)__. } \\
\text { 2- If you had a health-related question, whom would you ask first? Internet websites_, Doctors and Specialists__, } \\
\text { Friends and family (non-specialists), Books_, TV_, Newspapers and magazines_, Social media (Twitter, } \\
\text { Facebook, Instagram, etc.)__. } \\
\text { Coding: The variable was coded by taking the responses to the survey items 1-2. "Doctors and Specialists" were } \\
\text { coded as } 1 \text {, and } 0 \text { otherwise. The two items were tested for reliability with Cronbach's alpha, and then a single } \\
\text { generated scale was constructed. }\end{array}$ \\
\hline INT_FREQ & $\begin{array}{l}\text { Frequency use of the Internet. } \\
\text { Question: How often do you use the Internet? Every day_, 2-3 times a week__, Once a week__, Once in 2-3 weeks, } \\
\text { Once a month_, Once in } 3 \text { months_, Less than a few times a year__, Never__. } \\
\text { Coding: The score for the variable was coded by taking the responses to the question. Where the checked responses } \\
\text { to the ordered category choice sets (i.e. seven) were transformed into corresponding numerical values. The ordered } \\
\text { categories where responses were low were combined, resulting in three intervals. }\end{array}$ \\
\hline SM_FREQ & $\begin{array}{l}\text { Frequency use of Social Media. } \\
\text { Question: How often do you use social media? } 3 \text { hours a day or more__, 1-2 hours a day__, } 30 \text { mins a day__, Once a } \\
\text { day_, Few times a week_, Few times a month_, Once a month or less_, Never__. } \\
\text { Coding: The score for the variable was coded by taking the responses to the question. Where the checked responses } \\
\text { to the ordered category choice sets (i.e. eight) were transformed into corresponding numerical values. The ordered } \\
\text { categories where responses were low were combined, resulting in four intervals. }\end{array}$ \\
\hline AGE & $\begin{array}{l}\text { Age. } \\
\text { Question: Age: Less than } 18_{-}, 18-24_{-}, 25-30 \_, 31-35_{-}, 36-40 \_, 41-45_{-}, 46-50 \_, 51-60_{-}, 61-70_{-} . \\
\text {Coding: The variable was coded by taking the responses to the question, where the checked responses to the ordered } \\
\text { category choice sets (i.e. eight) were transformed into corresponding numerical values. }\end{array}$ \\
\hline GENDER & $\begin{array}{l}\text { Gender. } \\
\text { Question: Gender: Female__, Male_} \_ \text {. } \\
\text { Coding: The variable was coded by Female }=1 \text { and Male }=0 \text {. }\end{array}$ \\
\hline EDUCATION & $\begin{array}{l}\text { Education level. } \\
\text { Question: Education: Less than High School_, High school graduate__, Associate Degree_, Bachelor's degree__, } \\
\text { Master's degree_, } \mathrm{PhD} \_ \text {. } \\
\text { Coding: The variable was coded by taking the responses to the question, where the checked responses to the ordered } \\
\text { category choice sets (i.e. six) were transformed into corresponding numerical values. }\end{array}$ \\
\hline INCOME & $\begin{array}{l}\text { Household income level. } \\
\text { Question: Annual household income: Less than } \$ 20,00{ }_{\ldots}, \$ 20,000-\$ 49,000 \_, \$ 50,000-\$ 74,999 \_, \$ 75,000- \\
\$ 149,999 \_, \$ 150,000-\$ 249,999 \_, \$ 250,000 \text { or higher__. } \\
\text { Coding: The variable was coded by taking the responses to the question. Where the checked responses to the ordered } \\
\text { category choice sets (i.e. six) were transformed into corresponding numerical values. For the survey administered in } \\
\text { Kuwait, US dollar intervals were converted to equivalent Kuwaiti monetary figures accordingly. }\end{array}$ \\
\hline
\end{tabular}

sample is 18 years of age or less, $48 \%$ of the sample fall within the $18-24$ year age group, $21 \%$ fall in the 25-30 age group, $10 \%$ in the 31-35 age group, and the rest of the sample is above 35 years of age. Around $60 \%$ of the sample have at least a Bachelor education level, 14\% have Associate, $14 \%$ have high school and $10 \%$ of the sample have Masters or Ph.D. In terms of income level around $28 \%$ of the sample make less than $\$ 20,000$ annually, $22 \%$ make $\$ 20,000-\$ 49,000$, and the rest of the sample make $\$ 50,000$ or more. About $96 \%$ of the sample use the Internet on a daily basis and around $52 \%$ of the sample use social media for 3 hours a day or more. One interesting phenomenon observed is the greater reliance on the online information source for health-related information. For instance, of the survey participants who answered a survey question about the primary sources of health and medical information, $43 \%$ reported consulting a doctor or specialists, whereas $67 \%$ used the internet or social media. Although we had some concerns about the health background of the respondents, the fact that almost all the sample use the Internet on a daily basis and most of the sample uses the digital channels as a primary source of health information suggests that this sample was appropriate to examine knowledge conversion from the Internet and digital sources. Table 2 displays the descriptive statistics and the pairwise correlations amongst the variables. 


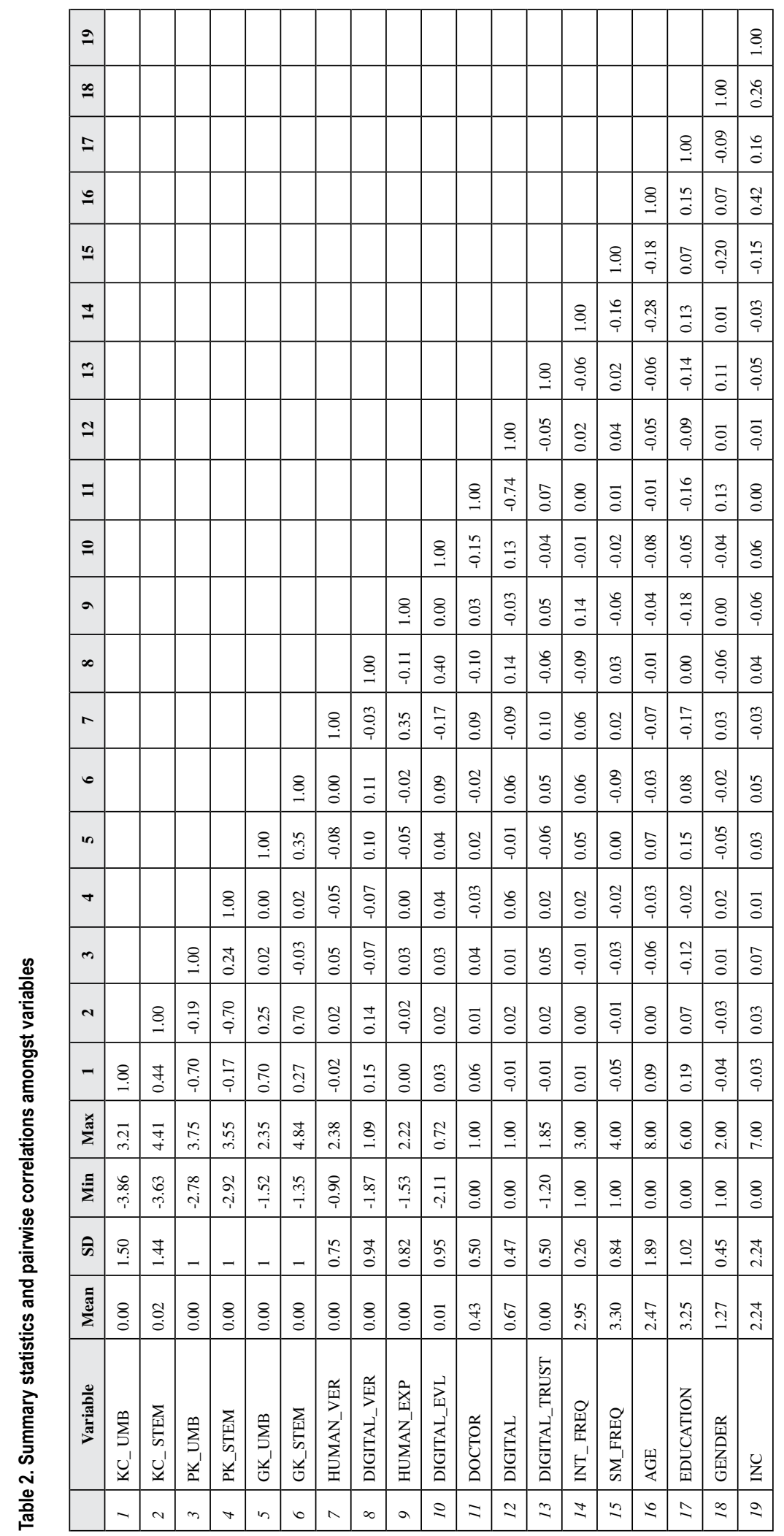


The main dependent variable to explore patients' medical practice decisions was operationalized with a questionnaire asking subjects whether they would consider undertaking a medical treatment procedure. The variable was operationalized using several questions written by a panel of stem cell specialists for each practice. General knowledge refers to the extent to which subjects possess general knowledge about the stem or umbilical cord as a potential treatment to improve one's health condition. Practice knowledge refers to the extent to which subjects are aware of facilities or places to receive stem and umbilical cord treatments to improve health conditions. The internal consistency of the items was tested using Cronbach's alpha, and the standardized score was generated for practice and general knowledge, respectively. Knowledge conversion is then derived by calculating the difference between the two scores.

The main variable of interest is the health information source; more specifically, knowledge acquired from a Digital Source (DIGITAL), such as the internet or social media. Intended use of health information source for knowledge validation is also considered, which comprise of knowledge evaluation and knowledge verification, the latter of which this study focuses on knowledge verification (DIGITAL_VER) as a key variable of interest in the model. The operationalization of these variables was accomplished by two questionnaires with multiple checklists of seven items. Subjects answered where they obtain health-related information, prior and post-doctor visits, respectively. Each selected checklist item was coded as a dummy variable, totaling six dummy variables. Factor analysis was used to reduce the dimensionality of the variables, and factors with the highest loading scores that represent human and digital sources were selected for inclusion in the model. Thus, four variables along the dimensions of health information source (i.e., human, digital) and knowledge purpose (i.e., evaluation vs. verification) are included in the model specification.

Trust in public health information for both direct and moderating effects of health information source on knowledge conversion and subsequent practice decision is then examined. More specifically, trust in the internet (TRUST_DIGITAL) as a public health information source. Last, cultural differences (individualistic culture versus collectivistic culture) are contrasted and operationalized (CULTURE) by a single questionnaire asking subjects about their place of residence - US or Kuwait.

In addition to these key variables of interest, several control variables are included to account for counterfactual explanations for knowledge conversion. Health information acquired from humans such as family or friends. In addition, whether or not the user has consulted doctors for health information, whether or not the user has used the internet or social media for health information. A user's trust score in public health and health practitioners. Frequency of internet use and frequency of social media use. Lastly, demographic variables such as age group, education level, gender, and income level are also controlled.

The empirical model specifies the knowledge conversion and practice decision of exclusive practices in health care as key dependent variables. Knowledge conversion and practice decision for two levels of EHP is operationalized, with stem cells and umbilical cord as a baseline and more EHP, respectively. Formal specification of the general model is as follows.

\section{Knowledge Conversion Model}

$$
\begin{aligned}
& \left(\text { KC_UMB }, \text { KC_STEM }_{\mathrm{i}}\right)=\beta_{0}+\beta_{1} \text { DIGITAL_VER }_{\mathrm{i}}+\beta_{2} \text { DIGITAL_TRUST }_{\mathrm{i}} \\
& +\beta_{3} \text { DIGITAL_VER }_{\mathrm{i}} \times \text { TRUST }+\beta_{4} \text { CULTURE }_{\mathrm{i}}+\beta_{\mathrm{c}} \text { Controls }_{\mathrm{i}}+\varepsilon_{\mathrm{i}}
\end{aligned}
$$

\section{Practice Decision Model}

$\left(D_{-}\right.$UMB, D_STEM $)=\beta_{0}+\beta_{1}$ DIGITAL_VER $_{\mathrm{i}}+\beta_{2}$ DIGITAL_TRUST $_{\mathrm{i}}$

$+\beta_{3}$ DIGITAL_VER $_{\mathrm{i}} \times$ TRUST $+\beta_{4}$ CULTURE $_{\mathrm{i}}+\beta_{\mathrm{c}}$ Controls $_{\mathrm{i}}+\beta_{10}$ KC_HAT $_{\mathrm{i}}+\varepsilon_{\mathrm{i}}$

where Controls are control variables, the general use of the Internet (INT_FREQ), the general use of social media (SM_FREQ), and several demographic variables including educational level (ED), age group (AGE), income (INCOME), and gender of the survey respondents (GENDER). 
Seemingly unrelated regression (SUR) is used to estimate the $\beta$ coefficients of the key parameters and employ robust standard errors to test the hypotheses. Last, $\varepsilon$ are disturbances associated with each observation. The practice decision model uses the predicted values of knowledge conversion from the first stage model (KC_HAT).

Table 3. Key estimation results and support for hypotheses

\begin{tabular}{|c|c|c|c|c|c|c|c|c|c|}
\hline \multirow{3}{*}{ Variables } & \multicolumn{4}{|c|}{ Knowledge Conversion } & \multicolumn{4}{|c|}{ Practice Decision } & \multirow{3}{*}{$\begin{array}{l}\text { Hypothesis } \\
\text { Supported }\end{array}$} \\
\hline & \multicolumn{2}{|c|}{ (1) } & \multicolumn{2}{|c|}{ (2) } & \multicolumn{2}{|c|}{ (1) } & \multicolumn{2}{|c|}{ (2) } & \\
\hline & KC_UMB & KC_STEM & KC_UMB & KC_STEM & D_UMB & D_STEM & D_UMB & D_STEM & \\
\hline $\begin{array}{l}\text { Knowledge } \\
\text { Conversion } \\
\text { (KC_STEM, KC_ } \\
\text { UMB) }\end{array}$ & & & & & $\begin{array}{l}0.546^{* * *} \\
(0.04)\end{array}$ & $\begin{array}{l}0.317 * * * \\
(0.04)\end{array}$ & $\begin{array}{l}0.544 * * * \\
(0.04)\end{array}$ & $\begin{array}{l}0.314 * * * \\
(0.04)\end{array}$ & $\begin{array}{l}\mathrm{H} 4 \\
\text { supported }\end{array}$ \\
\hline $\begin{array}{l}\text { Digital Source } \\
\text { (DIGITAL) }\end{array}$ & $\begin{array}{l}0.092 * \\
(0.05)\end{array}$ & $\begin{array}{l}0.103 * * \\
(0.05)\end{array}$ & & & $\begin{array}{l}-0.062 \\
(0.05)\end{array}$ & $\begin{array}{l}-0.011 \\
(0.06)\end{array}$ & & & $\begin{array}{l}\text { H1a } \\
\text { supported } \\
\text { H1b not } \\
\text { supported }\end{array}$ \\
\hline $\begin{array}{l}\text { Digital Knowledge } \\
\text { Verification } \\
\text { (DIGITAL_VER) }\end{array}$ & & & $\begin{array}{l}0.210^{* * * *} \\
(0.06)\end{array}$ & $\begin{array}{l}0.193 * * * \\
(0.06)\end{array}$ & & & $\begin{array}{l}-0.035 \\
(0.07)\end{array}$ & $\begin{array}{l}0.015 \\
(0.07)\end{array}$ & $\begin{array}{l}\text { H1a } \\
\text { supported } \\
\text { H1b not } \\
\text { supported }\end{array}$ \\
\hline $\begin{array}{l}\text { Trust on Internet } \\
\text { (DIGITAL_TRUST) }\end{array}$ & $\begin{array}{l}-0.003 \\
(0.05)\end{array}$ & $\begin{array}{l}0.049 \\
(0.05)\end{array}$ & $\begin{array}{l}0.009 \\
(0.05)\end{array}$ & $\begin{array}{l}0.055 \\
(0.05)\end{array}$ & $\begin{array}{l}-0.037 \\
(0.06)\end{array}$ & $\begin{array}{l}-0.003 \\
(0.06)\end{array}$ & $\begin{array}{l}-0.036 \\
(0.06)\end{array}$ & $\begin{array}{l}-0.002 \\
(0.06)\end{array}$ & $\begin{array}{l}\mathrm{H} 2 \text { not } \\
\text { supported }\end{array}$ \\
\hline $\begin{array}{l}\text { Digital Source } \mathrm{x} \\
\text { Trust } \\
\text { (DIGITAL x } \\
\text { DIGITAL_TRUST) }\end{array}$ & $\begin{array}{l}0.030 \\
(0.05)\end{array}$ & $\begin{array}{l}0.106^{* *} \\
(0.05)\end{array}$ & & & $\begin{array}{l}0.048 \\
(0.05)\end{array}$ & $\begin{array}{l}-0.044 \\
(0.06)\end{array}$ & & & $\begin{array}{l}\text { H3a } \\
\text { supported } \\
\text { H3b not } \\
\text { supported }\end{array}$ \\
\hline $\begin{array}{l}\text { Digital Verification } \\
\mathrm{x} \text { Trust (DIGITAL_ } \\
\text { VER } \times \text { DIGITAL_- } \\
\text { TRUST) }\end{array}$ & & & $\begin{array}{l}0.060 \\
(0.06)\end{array}$ & $\begin{array}{l}0.093 * \\
(0.06)\end{array}$ & & & $\begin{array}{l}0.041 \\
(0.06)\end{array}$ & $\begin{array}{l}-0.007 \\
(0.07)\end{array}$ & $\begin{array}{l}\text { H3a } \\
\text { supported } \\
\text { H3b not } \\
\text { supported }\end{array}$ \\
\hline $\begin{array}{l}\text { Culture } \\
\text { (CULTURE) }\end{array}$ & $\begin{array}{l}0.015 \\
(0.14)\end{array}$ & $\begin{array}{l}0.541^{* * * *} \\
(0.14)\end{array}$ & $\begin{array}{l}0.055 \\
(0.14)\end{array}$ & $\begin{array}{l}0.667 * * * \\
(0.14)\end{array}$ & $\begin{array}{l}0.220 \\
(0.15)\end{array}$ & $\begin{array}{l}0.431 * * \\
(0.17)\end{array}$ & $\begin{array}{l}0.201 \\
(0.16)\end{array}$ & $\begin{array}{l}0.474 * * * \\
(0.17)\end{array}$ & $\begin{array}{l}\text { H5a } \\
\text { supported. } \\
\text { H5b } \\
\text { supported. }\end{array}$ \\
\hline R-squared/Chi-sq. & 0.08 & 0.02 & 0.10 & 0.03 & $227.08 * * *$ & & $228.43 * * *$ & & \\
\hline Controls & \multicolumn{9}{|l|}{ YES } \\
\hline Observations & 721 & & & & 707 & & & & \\
\hline
\end{tabular}

Note: Robust standard errors in parentheses. Wald test was used to compare coefficients across two equations. Variable abbreviations in brackets represent dependent variables used in SUR. Variable abbreviations in parentheses represent independent variables. ${ }^{* *} p<0.01,{ }^{* *} p<0.05,{ }^{*} p<0.1$.

\section{RESULTS}

Table 3 displays the key results from two specification models. The medical practice decision is preceded by knowledge conversion. For each stage, two specifications operationalize knowledge validation from a digital source, which can further be decomposed into knowledge evaluation and verification, as a single composite variable for the first model, and as two independent variables for the second model, respectively. With the specification, the study compares and contrasts two related but different medical practices - i.e., umbilical cord and stem cells.

The first set of findings are relevant to the use of digital sources for knowledge verification on knowledge conversion and practice decision. The use of digital sources for health information has positive and significant coefficients across the two models on knowledge conversion. For a unit increase 
in the digital source (DIGITAL), individuals gain an approximately 0.1 unit increase in knowledge conversion. The digital knowledge conversion variables are standardized, and the interpretation of a unit change implies a unit change in the standard deviation. However, the digital source does not affect the practice decision.

An alternative specification for the digital source use for health information decomposes the digital source use from general to more specific; that is, the use of digital sources for knowledge verification, renders similar results. Our findings show that for those patients who use digital sources primarily to verify the information they have acquired, the effects positively influence knowledge verification. The coefficients on digital knowledge verification (DIGITAL_VER) is positive and statistically significant for both umbilical cords (i.e., $\beta=0.210$, p-level $<0.01$ ), and stem cells (i.e., $\beta=0.193$, p-level $<0.01$ ). However, digital knowledge verification does not affect the practice decision. Thus, the results from both specifications confirm that hypothesis H1a is supported, but $\mathrm{H} 1 \mathrm{~b}$ is not supported.

The second set of findings are relevant to the role of trust in the Internet, and how it affects patients' knowledge conversion and practice decision. Our findings show that the direct effect of trust in the Internet as a public source of health information (TRUST) does not influence knowledge conversion or practice decision. Thus, hypothesis $\mathrm{H} 2$ is not supported. However, our findings show that trust in the Internet positively moderates digital sources across both models. While the effect is positive for both umbilical cord and stem cells, the effect is statistically significant only for the stem cells (i.e., $\beta=0.106$, p-level $<0.01$ ). The result shows that the moderating effect of trust does not affect practice decisions. Thus, hypothesis $\mathrm{H} 3 \mathrm{a}$ is supported, but $\mathrm{H} 3 \mathrm{~b}$ is not supported.

Lastly, we test for the mediating effect of knowledge conversion on the practice decision. Our findings show that the coefficients for both umbilical practice decision (D_UMB) (i.e. $\beta=0.544$, p-level<0.01) and stem cell practice decision (D_STEM) (i.e., $\beta=0.314$, p-level<0.01) are positive and statistically significant. Thus, hypothesis H4 is supported. Sobel tests were conducted and found that that the mediation effect of knowledge conversion is partial, with less than $60 \%$ mediation effect influencing the practice decision.

Table 4. Robustness checks

\begin{tabular}{|c|c|c|c|c|}
\hline \multirow[t]{2}{*}{ Variables } & \multicolumn{2}{|c|}{$\begin{array}{l}\text { Knowledge } \\
\text { Conversion }\end{array}$} & \multicolumn{2}{|c|}{$\begin{array}{l}\text { Practice } \\
\text { Decision }\end{array}$} \\
\hline & KC_UMB & KC_STEM & D_UMB & D_STEM \\
\hline $\begin{array}{l}\text { Practice Knowledge } \\
\text { (PK_STEM, PK_UMB) }\end{array}$ & & & $\begin{array}{l}1.633 * * * \\
(0.11)\end{array}$ & $\begin{array}{l}0.875 * * * \\
(0.08)\end{array}$ \\
\hline $\begin{array}{l}\text { Digital Knowledge Verification } \\
\text { (DIGITAL_VER) }\end{array}$ & $\begin{array}{l}0.107 * * \\
(0.04)\end{array}$ & $\begin{array}{l}0.091 * * \\
(0.04)\end{array}$ & $\begin{array}{l}-0.061 \\
(0.09)\end{array}$ & $\begin{array}{l}-0.027 \\
(0.08)\end{array}$ \\
\hline $\begin{array}{l}\text { Trust on Internet } \\
\text { (TRUST) }\end{array}$ & $\begin{array}{l}0.003 \\
(0.04)\end{array}$ & $\begin{array}{l}0.048 \\
(0.04)\end{array}$ & $\begin{array}{l}-0.019 \\
(0.08)\end{array}$ & $\begin{array}{l}-0.049 \\
(0.07)\end{array}$ \\
\hline $\begin{array}{l}\text { Digital Verification } x \text { Trust } \\
\text { (DIGITAL_VER x TRUST) }\end{array}$ & $\begin{array}{l}0.079 * * \\
(0.04)\end{array}$ & $\begin{array}{l}0.090 * * \\
(0.04)\end{array}$ & $\begin{array}{l}-0.043 \\
(0.08)\end{array}$ & $\begin{array}{l}-0.056 \\
(0.08)\end{array}$ \\
\hline $\begin{array}{l}\text { Culture } \\
\text { (CULTURE) }\end{array}$ & $\begin{array}{l}0.077 \\
(0.10)\end{array}$ & $\begin{array}{l}0.310^{* * * *} \\
(0.10)\end{array}$ & $\begin{array}{l}0.234 \\
(0.22)\end{array}$ & $\begin{array}{l}0.746 * * * \\
(0.20)\end{array}$ \\
\hline R-squared/Chi-sq. & 0.06 & 0.04 & $331.80 * * *$ & \\
\hline Controls & \multicolumn{4}{|l|}{ YES } \\
\hline General Knowledge Control & \multicolumn{4}{|l|}{ YES } \\
\hline Observations & 721 & & 707 & \\
\hline
\end{tabular}

${ }^{*} \mathrm{p}<0.10,{ }^{* *} \mathrm{p}<0.05,{ }^{* * *} \mathrm{p} 0.01 ;+$ Variables in brackets represent equations estimated. 
Table 4 shows a similar result using an alternate specification of knowledge conversion, where practice knowledge with general knowledge as control was used to proxy knowledge conversion. Last, whether the differences in both exclusivities of practices and use of the digital source for verifying

Table 5. Comparison of digital verification: the U.S. vs. Kuwait ${ }^{+}$

\begin{tabular}{|l|l|l|l|l|}
\hline \multirow{2}{*}{ Variables } & \multicolumn{2}{c|}{$\begin{array}{c}\text { Knowledge } \\
\text { Conversion }\end{array}$} & \multicolumn{2}{c|}{$\begin{array}{c}\text { Practice } \\
\text { Decision }\end{array}$} \\
\cline { 2 - 5 } & KC_UMB & KC_STEM & D_UMB & $\begin{array}{c}\text { D__ } \\
\text { STEM }\end{array}$ \\
\hline Digital Knowledge Verification (DIGITAL_VER) & $5.88^{* * *}$ & $3.07^{*}$ & 0.00 & 0.64 \\
\hline Digital Verification $x$ Trust (DIGITAL_VER x TRUST) & $3.71^{*}$ & $3.66^{*}$ & 0.50 & 0.35 \\
\hline
\end{tabular}

${ }^{*} p<0.10,{ }^{* *} p<0.05,{ }^{* * *} p^{*} 0.01$; +Wald-test was employed to compare coefficients across subsamples drawn for U.S. and Kuwait. Chi-square statistics with statistical significance is displayed for knowledge conversion and practice decision.

health information acquired from medical experts influence knowledge conversion was tested.

As shown in Table 5, Wald-test was used to jointly test that the coefficients of digital knowledge verification and culture against the null hypothesis. The chi-square test statistics from Knowledge Conversion for both umbilical cord and stem cells support that digital verification and the moderating effect of trust on digital verification effects are different across Kuwait and the U.S. However, for Practice Decision, the difference across culture is not statistically significant. For Knowledge Conversion, subjects residing in Kuwait are more likely to exhibit higher knowledge conversion (i.e., 0.310 , p-level $<0.01$ ). For Practice Decision, subjects residing in Kuwait are more likely to undergo medical treatment for stem cells (i.e., 0.746, p-level $<0.01$ ), supporting hypotheses 5a, and 5b.

\section{DISCUSSION}

This study explores how the Internet is a factor in supporting the spread of stem cell therapy practices, viewing it from a knowledge validation theoretical perspective. The findings of this study provide interesting insights. The study finds that digital media as compared to offline media leads to higher levels of knowledge conversion in EHP and practice decisions. Knowledge verification in digital media leads to higher knowledge conversion and the decision to partake in practice.

Furthermore, trust in digital sources moderates the knowledge validation relationship, but only for less EHP. The relationships leading to knowledge conversion and practice decision are stronger for more collectivistic cultures, and cultures that are higher in power distance and uncertainty avoidance (e.g., Kuwait). These findings indicate that not only does the source of knowledge impact knowledge conversion, but also the knowledge validation process, the type of practice, and the culture impacts knowledge conversion and ultimately, the practice decision.

The finding that digital media leads to higher knowledge conversion and practice decision indicates the predominantly emerging role of the internet for health decision making as well as for deciding to partake in practice. Recent literature (Fox \& Duggan, 2013; Ma \& Atkin, 2017) asserts the developing role of the internet on health decision making. However, empirical validation has been sparse (Chen, Li, Liang, \& Tsai, 2018). In supporting the internet knowledge derived for health decision-making, not only this study informs literature; but it also provides insights on how the internet enables health empowerment to patients, in at least in two ways.

First, given the brick and mortar institutionalized healthcare practice prevalent in most countries, seeking health decisions or treatment is difficult and costly. Furthermore, stories of unsafe drugs and medical errors have led patients to want to know more about their medical conditions and treatment 
options (Tan \& Goonawardene, 2017). Patients now want medical information to be backed up by sound evidence (Calvillo, Román, \& Roa, 2015). In that realm, the internet has aided patients to become more proactive in making health-related decisions, reshaping the healthcare industry to become a more "patient-centric" industry.

Second, even if with the best health access, EHP may carry a stigma or reluctance to explore. For example, seeking information about HIV, or STD or plastic surgery is not a norm in many societies. That leads to satiation where the patients are reluctant to seek health, even if at an advanced stage of progression for some private diseases (Geana et al., 2017). The finding that the Internet can shape patients to explore health is informative in this sense, as enumerated in existing research (Permwonguswa, Khuntia, Yim, Gregg, \& Kathuria, 2017).

Another important finding is the moderating role of trust. Although digital media and knowledge verification are positively associated with knowledge conversion and practice decisions, the effect is enhanced when the individual trusts the Internet. When the type of information is more general than more exclusive, this finding shows that while the Internet can be a useful source for general or more established health practices, it might be confusing for newer or more EHP and therefore individuals would prefer attaining their knowledge from a human than the Internet.

This study also explores the digital knowledge verification relationship in different cultures. The relationship is more strongly supported for more collectivistic cultures, and cultures that are higher in power distance and uncertainty avoidance. This finding highlights the importance of culture in terms of the knowledge validation process for health information. The nature of the culture profoundly influences how a citizen of that culture searches and validates her information. In a collectivistic culture like Kuwait, physicians have absolute authority to decide on the treatment, and patients must trust their doctors (Tan \& Goonawardene, 2017). Patients in the collective culture seem to attain more knowledge conversion than patients in an individualistic culture. Such patients might feel a stronger need to validate their knowledge due to the hierarchal nature of the physician-patient relationship.

\section{Implications}

Knowledge validation and conversion concepts, although they have been suggested conceptually in existing literature, this study operationalizes and validates these concepts in a specific context. The practice concern of knowledge validation for exclusive treatments is a highly concerning aspect, and the role of the internet is underexplored. Within this realm, this study makes a significant contribution. To our knowledge, there is not a single study that addresses a theoretical tenet of 'exclusive knowledge validation' and that, to our knowledge is a significant contribution and direction for theory; and is a novel contribution to the information systems literature.

Beyond the new overarching concept of digital media knowledge validation framing, the study contributes to research in a couple of ways. First, the findings provide a deeper understanding of information systems artifacts in the health exclusive practice industry. The study suggests that the context of digital media validation has a critical role. Second, the study highlights the important role of trust in the media in terms of knowledge conversion and practice decision. Third, identifying how national culture interplays to influence knowledge conversion is a highlight of this study. These implications not only lead to unraveling the nuances associated with digital media knowledge validation but also extend concepts such as why certain types of cultures can have higher knowledge conversion than others.

In terms of managerial implications, health care providers should now be aware of the Internet informed patient. Thus, health care providers should help patients sort through the information derived from the Internet information offered by patients and guide them to reliable and accurate health websites (T. Lu et al., 2018; X. Lu, Zhang, Wu, Shang, \& Liu, 2018). Healthcare organizations should utilize the power and impact of the Internet to their advantage by providing valuable digital information that can assist patients and link them to credible health-related digital information. 
Furthermore, health knowledge websites now have a very strong role in the knowledge conversion of patients. Thus, these websites need to ensure that the information provided is easy to interpret and accurate (Maity et al., 2018).

\section{Study Limitations}

This study examines how patients validate their knowledge in the knowledge conversion process at a point in time. However, the patient might go back and forth in the learning process, and the validation method and source may change over time. This is a limitation of the study. Future studies could examine how a patient's learning behavior changes over time. Also, using the random sampling process of the public in both the US and Kuwait may include less familiar respondents to the study context. Thus, the generalization of the sample to a uniform national culture characteristic is a limitation of this study. A future study may focus on patients of such EHP and examine their knowledge validation and conversion directly.

\section{CONCLUSION}

In conclusion, this study is the first to propose a knowledge validation framing for health information in the EHP context. The concept of knowledge validation framing is explored using trust and type of EHP to provide a richer investigation of the knowledge conversion process and ultimately practice decision. Furthermore, knowledge validation interactions with the information source and trust in information sources draw further insights into the knowledge conversion process. The findings provide important insights that can be used by researchers to investigate different aspects of knowledge conversion further and by health policy management practitioners to develop strategies to increase the reliability of the available information.

\section{FUNDING AGENCY}

Open Access Funding for this article has been provided by (Kuwait University) [grant numbers IQ03/17].

\section{ACKNOWLEDGMENT}

This study has been funded by Kuwait University [Grant Number IQ03/17]. I would like to thank Kuwait University's Research Administration for granting the project and facilitating the research implementation. 


\section{REFERENCES}

Åkerman, N. (2015). Knowledge-acquisition strategies and the effects on market knowledge-profiling the internationalizing firm. European Management Journal, 33(2), 79-88. doi:10.1016/j.emj.2014.06.003

Ali, H., \& Al-Mulla, F. (2012). Defining umbilical cord blood stem cells. Stem Cell Discovery, 2(1), 15-23. doi:10.4236/scd.2012.21003

Alnafea, S., Fedele, S., Porter, S., \& Ni Riordain, R. (2017). Online Information on the Treatment of Burning Mouth Syndrome: Quality and Readability. Journal of Oral \& Facial Pain and Headache, 31(2), 147-151. doi:10.11607/ofph.1717 PMID:28437511

Anandarajan, M., Zaman, M., Dai, Q., \& Arinze, B. (2010). Generation Y adoption of instant messaging: An examination of the impact of social usefulness and media richness on use richness. IEEE Transactions on Professional Communication, 53(2), 132-143. doi:10.1109/TPC.2010.2046082

Archak, N., Ghose, A., \& Ipeirotis, P. G. (2011). Deriving the pricing power of product features by mining consumer reviews. Management Science, 57(8), 1485-1509. doi:10.1287/mnsc.1110.1370

Argote, L., McEvily, B., \& Reagans, R. (2003). Managing knowledge in organizations: An integrative framework and review of emerging themes. Management Science, 49(4), 571-582. doi:10.1287/mnsc.49.4.571.14424

Arif, N., \& Ghezzi, P. (2018). Quality of online information on breast cancer treatment options. The Breast, 37, 6-12. doi:10.1016/j.breast.2017.10.004 PMID:29040893

Attar, M., Kang, K., \& Sohaib, O. (2019). Knowledge Sharing Practices, Intellectual Capital and Organizational Performance. Proceedings of the 52nd Hawaii International Conference on System Sciences. doi:10.24251/ HICSS.2019.671

Berger, M., Wagner, T. H., \& Baker, L. C. (2005). Internet use and stigmatized illness. Social Science \& Medicine, 61(8), 1821-1827. doi:10.1016/j.socscimed.2005.03.025 PMID:16029778

Berger, \& Milkman, K. L. (2012). What makes online content viral? Journal of Marketing Research, 49(2), 192-205.

Berkowitz, A. L., Miller, M. B., Mir, S. A., Cagney, D., Chavakula, V., Guleria, I., Aizer, A., Ligon, K. L., \& Chi, J. H. (2016). Glioproliferative Lesion of the Spinal Cord as a Complication of "Stem-Cell Tourism". The New England Journal of Medicine, 375(2), 196-198. doi:10.1056/NEJMc1600188 PMID:27331440

Bhagat, R. S., Kedia, B. L., Harveston, P. D., \& Triandis, H. C. (2002). Cultural variations in the cross-border transfer of organizational knowledge: An integrative framework. Academy of Management Review, 27(2), 204-221. doi:10.5465/amr.2002.6588000

Bjørk, I. T., Lomborg, K., Nielsen, C. M., Brynildsen, G., Frederiksen, A. M. S., Larsen, K., Reierson, I. Å., Sommer, I., \& Stenholt, B. (2013). From theoretical model to practical use: An example of knowledge translation. Journal of Advanced Nursing, 69(10), 2336-2347. doi:10.1111/jan.12091 PMID:23387968

Calvillo, J., Román, I., \& Roa, L. M. (2015). How technology is empowering patients? A literature review. Health Expectations, 18(5), 643-652. doi:10.1111/hex.12089 PMID:23711169

Carlson, J. R., \& Zmud, R. W. (1999). Channel expansion theory and the experiential nature of media richness perceptions. Academy of Management Journal, 42(2), 153-170.

Casillas, J. C., Barbero, J. L., \& Sapienza, H. J. (2015). Knowledge acquisition, learning, and the initial pace of internationalization. International Business Review, 24(1), 102-114. doi:10.1016/j.ibusrev.2014.06.005

Chang, H. H., \& Chen, S. W. (2008). The impact of customer interface quality, satisfaction and switching costs on e-loyalty: Internet experience as a moderator. Computers in Human Behavior, 24(6), 2927-2944. doi:10.1016/j. chb.2008.04.014

Chen, Y.-Y., Li, C.-M., Liang, J.-C., \& Tsai, C.-C. (2018). Health information obtained from the internet and changes in medical decision making: Questionnaire development and cross-sectional survey. Journal of Medical Internet Research, 20(2), e47. doi:10.2196/jmir.9370 PMID:29434017 
Cossu, G., Birchall, M., Brown, T., De Coppi, P., Culme-Seymour, E., Gibbon, S., \& Morris, S. et al. (2018). Lancet commission: Stem cells and regenerative medicine. Lancet, 391(10123), 883-910. doi:10.1016/S01406736(17)31366-1 PMID:28987452

Cyr, D. (2013). Website design, trust and culture: An eight country investigation. Electronic Commerce Research and Applications, 12(6), 373-385. doi:10.1016/j.elerap.2013.03.007

Daft, R. L., \& Lengel, R. H. (1986). Organizational information requirements, media richness and structural design. Management Science, 32(5), 554-571. doi:10.1287/mnsc.32.5.554

Daraz, L., Morrow, A. S., Ponce, O. J., Beuschel, B., Farah, M. H., Katabi, A., \& Seisa, M. O. et al. (2019). Can Patients Trust Online Health Information? A Meta-narrative Systematic Review Addressing the Quality of Health Information on the Internet. Journal of General Internal Medicine, 34(9), 1-8. doi:10.1007/s11606019-05109-0 PMID:31228051

de Mooij, M. (2017). Comparing dimensions of national culture for secondary analysis of consumer behavior data of different countries. International Marketing Review, 34(3), 444-456. doi:10.1108/IMR-02-2016-0047

Dresser, R. (2010). Stem Cell Research as Innovation: Expanding the Ethical and Policy Conversation. The Journal of Law, Medicine \& Ethics, 38(2), 332-341.

Durcikova, A., \& Gray, P. (2009). How knowledge validation processes affect knowledge contribution. Journal of Management Information Systems, 25(4), 81-108. doi:10.2753/MIS0742-1222250403

Ernst, M. M., Chen, D., Kennedy, K., Jewell, T., Sajwani, A., Foley, C., \& Sandberg, D. E. (2019). Disorders of sex development (DSD) web-based information: Quality survey of DSD team websites. International Journal of Pediatric Endocrinology, 2019(1), 1. doi:10.1186/s13633-019-0065-x PMID:31149017

Eysenbach, G., \& Jadad, A. R. (2001). Evidence-based patient choice and consumer health informatics in the Internet age. Journal of Medical Internet Research, 3(2), e19. doi:10.2196/jmir.3.2.e19 PMID:11720961

FDA. (2017). FDA Warns About Stem Cell Therapies. U.S. Food \& Drug Administration.

FDA. (2018). Clinical Research Versus Medical Treatment. U.S. Department of Health and Human Services.

Fox, S., \& Duggan, M. (2013). Health online 2013. Health, 2013, 1-55.

Frieden, T. R. (2017). Evidence for health decision making-Beyond randomized, controlled trials. The New England Journal of Medicine, 377(5), 465-475. doi:10.1056/NEJMra1614394 PMID:28767357

Gagné, M. E., \& Boulet, L.-P. (2018). Implementation of asthma clinical practice guidelines in primary care: A cross-sectional study based on the Knowledge-to-Action Cycle. The Journal of Asthma, 55(3), 310-317. doi:1 0.1080/02770903.2017.1323919 PMID:28548896

Garcia, S. (2014). The effects of education on anxiety levels in patients receiving chemotherapy for the first time: An integrative review. Clinical Journal of Oncology Nursing, 18(5), 516-521. doi:10.1188/14.CJON.1805AP PMID:25164233

Geana, M., Erba, J., Krebill, H., Doolittle, G., Madhusudhana, S., Qasem, A., Malomo, N., \& Sharp, D. (2017). Searching for cures: Inner-city and rural patients' awareness and perceptions of cancer clinical trials. Contemporary Clinical Trials Communications, 5, 72-79. doi:10.1016/j.conctc.2016.12.004 PMID:29740623

Gefen, D., Karahanna, E., \& Straub, D. W. (2003). Trust and TAM in online shopping: An integrated model. Management Information Systems Quarterly, 27(1), 51-90. doi:10.2307/30036519

George, B. (2011). Regulations and guidelines governing stem cell based products: Clinical considerations. Perspectives in Clinical Research, 2(3), 94. doi:10.4103/2229-3485.83228 PMID:21897884

Glasgow, R. E. M., \& David, J. (2005). Practical Clinical Trials for Translating Research to Practice: Design and Measurement Recommendations. Medical Care, 43(6), 551-557. doi:10.1097/01.mlr.0000163645.41407.09 PMID:15908849

Gonzalez-Loureiro, M., Sousa, M. J., \& Pinto, H. (2017). Culture and innovation in SMEs: The intellectual structure of research for further inquiry. European Planning Studies, 25(11), 1908-1931. doi:10.1080/096543 13.2017.1290052 
Gottfried, J., \& Shearer, E. (2016). News use across social media platforms 2016. Pew Research Center.

Graham, I. D., Logan, J., Harrison, M. B., Straus, S. E., Tetroe, J., Caswell, W., \& Robinson, N. (2006). Lost in knowledge translation: Time for a map? The Journal of Continuing Education in the Health Professions, 26(1), 13-24. doi:10.1002/chp.47 PMID:16557505

Grimm, S. E., Pouwels, X., Ramaekers, B. L., Wijnen, B., Knies, S., Grutters, J., \& Joore, M. A. (2019). Development and Validation of the TRansparent Uncertainty ASsessmenT (TRUST) Tool for Assessing Uncertainties in Health Economic Decision Models. PharmacoEconomics, 1-12. PMID:31709496

Guzzo, R. M., \& O’Sullivan, M. B. (2016). Human Pluripotent Stem Cells: Advances in Chondrogenic Differentiation and Articular Cartilage Regeneration. Current Molecular Biology Reports, 2(3), $113-122$. doi:10.1007/s40610-016-0041-7

Hofstede, G. (2003). Culture's consequences: Comparing values, behaviors, institutions and organizations across nations. Sage Publications.

Hou, J., \& Shim, M. (2010). The role of provider-patient communication and trust in online sources in Internet use for health-related activities. Journal of Health Communication, 15(sup3), 186-199.

Hua, D., Carter, S., Bellerive, J., Allu, S. O., Reid, D., Tremblay, G., Lindsay, P., \& Tobe, S. W. (2012). Bridging the gap: Innovative knowledge translation and the Canadian hypertension education program. The Canadian Journal of Cardiology, 28(3), 258-261. doi:10.1016/j.cjca.2012.03.011 PMID:22483787

Huo, C., Zhang, M., \& Ma, F. (2018). Factors influencing people's health knowledge adoption in social media: The mediating effect of trust and the moderating effect of health threat. Library Hi Tech, 36(1), 129-151. doi:10.1108/LHT-04-2017-0074

Jiang, S., \& Beaudoin, C. E. (2016). Health literacy and the internet: An exploratory study on the 2013 HINTS survey. Computers in Human Behavior, 58, 240-248. doi:10.1016/j.chb.2016.01.007

Josefsson, U. (2006). Patients' online information seeking behavior. The internet and health care: Theory, research, and practice, 127-147.

Kim, K., Lustria, M. L. A., Burke, D., \& Kwon, N. (2007). Predictors of cancer information overload: Findings from a national survey. Information Research, 12(4), 12-14.

King, N. M., \& Perrin, J. (2014). Ethical issues in stem cell research and therapy. Stem Cell Research \& Therapy, 5(4), 85. doi:10.1186/scrt474 PMID:25157428

Klein, J. D., \& Wilson, K. M. (2002). Delivering quality care: Adolescents' discussion of health risks with their providers. The Journal of Adolescent Health, 30(3), 190-195. doi:10.1016/S1054-139X(01)00342-1 PMID:11869926

Knoepfler, P. S., \& Turner, L. G. (2018). The FDA and the US direct-to-consumer marketplace for stem cell interventions: A temporal analysis. Regenerative Medicine, 13(1), 19-27. doi:10.2217/rme-2017-0115 PMID:29327974

Kock, N. (2005). Media richness or media naturalness? The evolution of our biological communication apparatus and its influence on our behavior toward e-communication tools. IEEE Transactions on Professional Communication, 48(2), 117-130. doi:10.1109/TPC.2005.849649

Kuriyan, A. E., Albini, T. A., Townsend, J. H., Rodriguez, M., Pandya, H. K., Leonard, R. E. I. II, Parrott, M. B., Rosenfeld, P. J., Flynn, H. W. Jr, \& Goldberg, J. L. (2017). Vision Loss after Intravitreal Injection of Autologous "Stem Cells" for AMD. The New England Journal of Medicine, 376(11), 1047-1053. doi:10.1056/ NEJMoa1609583 PMID:28296617

Lane, V. R., Khuntia, J., Parthasarathy, M., \& Hazarika, B. B. (2017). The Impact of the Internet on Values in India: Shifts in Self-Enhancement and Self-Transcendence Amongst Indian Youth. Journal of Global Information Management, 25(3), 98-120. doi:10.4018/JGIM.2017070106

Lengel, R. H., \& Daft, R. L. (1988). The selection of communication media as an executive skill. The Academy of Management Perspectives, 2(3), 225-232. doi:10.5465/ame.1988.4277259 
Lipowski, M., \& Bondos, I. (2018). The influence of perceived media richness of marketing channels on online channel usage: Intergenerational differences. Baltic Journal of Management, 13(2), 169-190. doi:10.1108/ BJM-04-2017-0127

Liu, Y., Tan, C.-H., \& Sutanto, J. (2018). A media symbolism perspective on the choice of social sharing technologies. Electronic Commerce Research and Applications, 29, 19-29. doi:10.1016/j.elerap.2018.03.001

Lozoya, R. C., Berte, B., Cochet, H., Jaïs, P., Ayache, N., \& Sermesant, M. (2018). Model-based feature augmentation for cardiac ablation target learning from images. IEEE Transactions on Biomedical Engineering, 66(1), 30-40. doi:10.1109/TBME.2018.2818300 PMID:29993400

Lu, T., Xu, Y., \& Wallace, S. (2018). Internet usage and patient's trust in physician during diagnoses: A knowledge power perspective. Journal of the Association for Information Science and Technology, 69(1), 110-120. doi:10.1002/asi.23920

Lu, X., Zhang, R., Wu, W., Shang, X., \& Liu, M. (2018). Relationship between internet health information and patient compliance based on trust: Empirical study. Journal of Medical Internet Research, 20(8), e253. doi:10.2196/jmir.9364 PMID:30120087

Lucas, L. M. (2006). The role of culture on knowledge transfer: The case of the multinational corporation. The Learning Organization, 13(3), 257-275. doi:10.1108/09696470610661117

Ma, T. J., \& Atkin, D. (2017). User generated content and credibility evaluation of online health information: A meta analytic study. Telematics and Informatics, 34(5), 472-486. doi:10.1016/j.tele.2016.09.009

Maity, M., \& Dass, M. (2014). Consumer decision-making across modern and traditional channels: E-commerce, m-commerce, in-store. Decision Support Systems, 61, 34-46. doi:10.1016/j.dss.2014.01.008

Maity, M., Dass, M., \& Kumar, P. (2018). The impact of media richness on consumer information search and choice. Journal of Business Research, 87, 36-45. doi:10.1016/j.jbusres.2018.02.003

Mandai, M., Watanabe, A., Kurimoto, Y., Hirami, Y., Morinaga, C., Daimon, T., Fujihara, M., Akimaru, H., Sakai, N., Shibata, Y., Terada, M., Nomiya, Y., Tanishima, S., Nakamura, M., Kamao, H., Sugita, S., Onishi, A., Ito, T., Fujita, K., \& Takahashi, M. et al. (2017). Autologous Induced Stem-Cell-Derived Retinal Cells for Macular Degeneration. The New England Journal of Medicine, 376(11), 1038-1046. doi:10.1056/NEJMoa1608368 PMID:28296613

Marsh, K., IJzerman, M., Thokala, P., Baltussen, R., Boysen, M., Kaló, Z., \& Watkins, J. et al. (2016). Multiple criteria decision analysis for health care decision making - emerging good practices: Report 2 of the ISPOR MCDA Emerging Good Practices Task Force. Value in Health, 19(2), 125-137. doi:10.1016/j.jval.2015.12.016 PMID:27021745

Massey, A. P., \& Montoya-Weiss, M. M. (2006). Unraveling the temporal fabric of knowledge conversion: A model of media selection and use. Management Information Systems Quarterly, 30(1), 99-114. doi:10.2307/25148719

McKnight, D. H., Choudhury, V., \& Kacmar, C. (2002). The impact of initial consumer trust on intentions to transact with a web site: A trust building model. The Journal of Strategic Information Systems, 11(3-4), 297-323. doi:10.1016/S0963-8687(02)00020-3

Meghan, M. Y., Paul, H. Y., Hussein, K. I., Cross, M. B., \& Della Valle, C. J. (2017). Readability of Patient Education Materials From the Web Sites of Orthopedic Implant Manufacturers. The Journal of Arthroplasty, 32(12), 3568-3572. doi:10.1016/j.arth.2017.07.003 PMID:28750856

Murdoch, B., Zarzeczny, A., \& Caulfield, T. (2018). Exploiting science? A systematic analysis of complementary and alternative medicine clinic websites' marketing of stem cell therapies. BMJ Open, 8(2), e019414. doi:10.1136/ bmjopen-2017-019414 PMID:29490963

Nguyen, A., Mosadeghi, S., \& Almario, C. V. (2017). Persistent digital divide in access to and use of the Internet as a resource for health information: Results from a California population-based study. International Journal of Medical Informatics, 103, 49-54. doi:10.1016/j.jjmedinf.2017.04.008 PMID:28551001

Nisar, T. M., Prabhakar, G., \& Strakova, L. (2019). Social media information benefits, knowledge management and smart organizations. Journal of Business Research, 94, 264-272. doi:10.1016/j.jbusres.2018.05.005 
Olteanu, A., Castillo, C., Diaz, F., \& Kiciman, E. (2019). Social data: Biases, methodological pitfalls, and ethical boundaries. Frontiers in Big Data, 2, 13. doi:10.3389/fdata.2019.00013

Paarlberg, R. L. (2005). The great stem cell race. Foreign Policy, (148), 44.

Paulin, D., \& Suneson, K. (2015). Knowledge transfer, knowledge sharing and knowledge barriers-three blurry terms in KM. Leading Issues in Knowledge Management, 2(2), 73.

Permwonguswa, S., Khuntia, J., Yim, D., Gregg, D., \& Kathuria, A. (2017). Knowledge sharing in a health infomediary: Role of self-concept, emotional empowerment, and self-esteem. Health Systems (Basingstoke, England), 1-14. PMID:31214347

Qiu, X., Oliveira, D. F., Shirazi, A. S., Flammini, A., \& Menczer, F. (2017). Limited individual attention and online virality of low-quality information. Nature Human Behaviour, 1(7), 0132.

Reinecke, L., Aufenanger, S., Beutel, M. E., Dreier, M., Quiring, O., Stark, B., Wölfling, K., \& Müller, K. W. (2017). Digital stress over the life span: The effects of communication load and internet multitasking on perceived stress and psychological health impairments in a German probability sample. Media Psychology, 20(1), 90-115. doi:10.1080/15213269.2015.1121832

Saad, E. D., Paoletti, X., Burzykowski, T., \& Buyse, M. (2017). Precision medicine needs randomized clinical trials. Nature Reviews. Clinical Oncology, 14(5), 317-323. doi:10.1038/nrclinonc.2017.8 PMID:28169302

Sbaffi, L., \& Rowley, J. (2017). Trust and credibility in web-based health information: A review and agenda for future research. Journal of Medical Internet Research, 19(6), e218. doi:10.2196/jmir.7579 PMID:28630033

Seay, H. R., Putnam, A. L., Cserny, J., Posgai, A. L., Rosenau, E. H., Wingard, J. R., \& Brown, H. L. et al. (2017). Expansion of human Tregs from cryopreserved umbilical cord blood for GMP-compliant autologous adoptive cell transfer therapy. Molecular Therapy. Methods \& Clinical Development, 4, 178-191. doi:10.1016/j. omtm.2016.12.003 PMID:28345003

Shearer, E., \& Gottfried, J. (2017). News use across social media platforms 2017. Pew Research Center, 49(1), $1-17$.

Sillence, E., Briggs, P., Harris, P. R., \& Fishwick, L. (2007). How do patients evaluate and make use of online health information? Social Science \& Medicine, 64(9), 1853-1862. doi:10.1016/j.socscimed.2007.01.012 PMID: 17328998

Singh, S. (2006). Cultural differences in, and influences on, consumers' propensity to adopt innovations. International Marketing Review, 23(2), 173-191. doi:10.1108/02651330610660074

Sohaib, O., \& Kang, K. (2017). E-commerce web accessibility for people with disabilities Complexity in Information Systems Development. Springer.

Sohaib, O., Kang, K., \& Miliszewska, I. (2019). Uncertainty Avoidance and Consumer Cognitive Innovativeness in E-Commerce. Journal of Global Information Management, 27(2), 59-77. doi:10.4018/JGIM.2019040104

Sohaib, O., Kang, K., \& Nurunnabi, M. (2019). Gender-Based iTrust in E-Commerce: The Moderating Role of Cognitive Innovativeness. Sustainability, 11(1), 175. doi:10.3390/su11010175

Stacey, D., Higuchi, K. A., Menard, P., Davies, B., Graham, I. D., \& O’Connor, A. M. (2009). Integrating patient decision support in an undergraduate nursing curriculum: An implementation project. International Journal of Nursing Education Scholarship, 6(1). Advance online publication. doi:10.2202/1548-923X.1741 PMID:19341354

Stump, R. L., \& Gong, W. (2017). Social networking sites: An exploration of the effect of national cultural dimensions on country adoption rates and usage patterns. International Journal of Electronic Business, 13(2-3), 117-142. doi:10.1504/IJEB.2017.083288

Suh, K. S. (1999). Impact of communication medium on task performance and satisfaction: An examination of media-richness theory. Information \& Management, 35(5), 295-312. doi:10.1016/S0378-7206(98)00097-4

Sundberg, L. R., Garvare, R., \& Nyström, M. E. (2017). Reaching beyond the review of research evidence: A qualitative study of decision making during the development of clinical practice guidelines for disease prevention in healthcare. BMC Health Services Research, 17(1), 344. doi:10.1186/s12913-017-2277-1 PMID:28490325 
Swar, B., Hameed, T., \& Reychav, I. (2017). Information overload, psychological ill-being, and behavioral intention to continue online healthcare information search. Computers in Human Behavior, 70, 416-425. doi:10.1016/j.chb.2016.12.068

Tan, S. S.-L., \& Goonawardene, N. (2017). Internet health information seeking and the patient-physician relationship: A systematic review. Journal of Medical Internet Research, 19(1), e9. doi:10.2196/jmir.5729 PMID:28104579

ter Hoeven, C. L., Stohl, C., Leonardi, P., \& Stohl, M. (2019). Assessing Organizational Information Visibility: Development and Validation of the Information Visibility Scale. Communication Research, 0093650219877093. doi: $10.1177 / 0093650219877093$

Thoumrungroje, A. (2018). Entrepreneurial intensity, national culture, and the success of new product developments: The mediating role of information technology. AU Journal of Management, 1(1), 15-23.

Tian, M., Deng, P., Zhang, Y., \& Salmador, M. P. (2018). How does culture influence innovation? A systematic literature review. Management Decision, 56(5), 1088-1107. doi:10.1108/MD-05-2017-0462

Triandis, H. C. (2018). Individualism and collectivism. Routledge. doi:10.4324/9780429499845

Tseng, F.-C., Cheng, T., Li, K., \& Teng, C.-I. (2017). How does media richness contribute to customer loyalty to mobile instant messaging? Internet Research, 27(3), 520-537. doi:10.1108/IntR-06-2016-0181

van Woerkom, M., \& Sanders, K. (2010). The romance of learning from disagreement. The effect of cohesiveness and disagreement on knowledge sharing behavior and individual performance within teams. Journal of Business and Psychology, 25(1), 139-149. doi:10.1007/s10869-009-9136-y PMID:20174445

Vaquero, J., Zurita, M., Rico, M., Aguayo, C., Fernández, C., Gutiérrez, R., Rodríguez-Boto, G., Saab, A., Hassan, R., \& Ortega, C. (2018). Intrathecal administration of autologous bone marrow stromal cells improves neuropathic pain in patients with spinal cord injury. Neuroscience Letters, 670, 14-18. doi:10.1016/j.neulet.2018.01.035 PMID:29366770

von Tigerstrom, B. (2017). Regulating the advertising and promotion of stem cell therapies. Regenerative Medicine, 12(7), 815-826. doi:10.2217/rme-2017-0057 PMID:29112482

Yun, J. J., Mohan, A. V., \& Zhao, X. (2017). Collectivism, Individualism and Open Innovation: Introduction to the Special Issue on 'Technology, Open Innovation, Markets and Complexity'. Science, Technology \& Society, 22(3), 379-387. doi:10.1177/0971721817736439

Zeffane, R. (2017). Gender, individualism-collectivism and individuals' propensity to trust: A comparative exploratory study. Journal of Management \& Organization, 1-15. doi:10.1017/jmo.2017.57 


\section{APPENDIX}

Table 6. Age group of respondents

\begin{tabular}{|l|l|l|l|}
\hline \multicolumn{1}{|c|}{ Age Group } & \multicolumn{1}{c|}{ \% of Responses } & \multicolumn{1}{c|}{ US } & \multicolumn{1}{c|}{ Kuwait } \\
\hline $0-$ Less than18 & $1.92 \%$ & $0.00 \%$ & $2.77 \%$ \\
\hline $1-18-24$ & $48.76 \%$ & $71.17 \%$ & $38.93 \%$ \\
\hline $2-25-30$ & $21.84 \%$ & $19.37 \%$ & $22.92 \%$ \\
\hline $3-31-35$ & $10.16 \%$ & $5.41 \%$ & $12.25 \%$ \\
\hline $4-36-40$ & $5.49 \%$ & $2.70 \%$ & $6.72 \%$ \\
\hline $5-41-45$ & $3.30 \%$ & $1.35 \%$ & $4.15 \%$ \\
\hline $6-46-50$ & $4.26 \%$ & $0.00 \%$ & $6.13 \%$ \\
\hline $7-51-60$ & $3.71 \%$ & $0.00 \%$ & $5.34 \%$ \\
\hline $8-61-70$ & $0.55 \%$ & $0.00 \%$ & $0.79 \%$ \\
\hline
\end{tabular}

Table 7. Gender of respondents

\begin{tabular}{|l|l|l|l|}
\hline \multicolumn{1}{|c|}{ Gender } & \multicolumn{1}{|c|}{ \% of Responses } & \multicolumn{1}{c|}{ Kuwait } \\
\hline $1-$ Female & $63.86 \%$ & $45.22 \%$ & $72.33 \%$ \\
\hline $2-$ Male & $36.14 \%$ & $54.78 \%$ & $27.67 \%$ \\
\hline
\end{tabular}

Table 8. Education level of respondents

\begin{tabular}{|l|l|l|l|}
\hline \multicolumn{1}{|c|}{ Education Level } & \multicolumn{1}{c|}{ \% of Responses } & \multicolumn{1}{c|}{ US } & \multicolumn{1}{c|}{ Kuwait } \\
\hline 0 - Less than High School & $1.09 \%$ & $0.00 \%$ & $1.58 \%$ \\
\hline 1 - High School & $14.03 \%$ & $31.58 \%$ & $6.13 \%$ \\
\hline 2 - Associates & $14.44 \%$ & $26.75 \%$ & $8.89 \%$ \\
\hline $3-$ Bachelor & $60.22 \%$ & $39.91 \%$ & $69.37 \%$ \\
\hline $4-$ Masters & $6.40 \%$ & $0.88 \%$ & $8.89 \%$ \\
\hline $5-\mathrm{PhD}$ & $3.81 \%$ & $0.88 \%$ & $5.14 \%$ \\
\hline
\end{tabular}

Table 9. Income category level of respondents

\begin{tabular}{|l|l|l|l|}
\hline \multicolumn{1}{|c|}{ Income Category } & \multicolumn{1}{c|}{ \% of Responses } & \multicolumn{1}{c|}{ US } & \multicolumn{1}{c|}{ Kuwait } \\
\hline $1-$ Less than $\$ 20,000$ & $28.19 \%$ & $23.04 \%$ & $30.89 \%$ \\
\hline $2-\$ 20,000-\$ 49,000$ & $22.94 \%$ & $30.00 \%$ & $19.22 \%$ \\
\hline $3-\$ 50,000-\$ 74,999$ & $26.54 \%$ & $20.43 \%$ & $29.75 \%$ \\
\hline $4-\$ 75,000-\$ 149,999$ & $15.89 \%$ & $18.70 \%$ & $14.42 \%$ \\
\hline $5-\$ 150,000-\$ 249,999$ & $3.60 \%$ & $3.48 \%$ & $3.66 \%$ \\
\hline $6-\$ 250,000$ or higher & $2.85 \%$ & $4.35 \%$ & $2.06 \%$ \\
\hline
\end{tabular}


Table 10. Internet use frequency of respondents

\begin{tabular}{|l|l|l|l|}
\hline \multicolumn{1}{|c|}{ Internet Use Frequency } & \multicolumn{1}{c|}{ \% of Responses } & \multicolumn{1}{c|}{ US } & \multicolumn{1}{c|}{ Kuwait } \\
\hline 1 - Once a week or less* & $1.08 \%$ & $0.43 \%$ & $1.38 \%$ \\
\hline 2 - 2-3 times a week & $2.57 \%$ & $1.29 \%$ & $3.16 \%$ \\
\hline 3 - Everyday & $96.34 \%$ & $98.28 \%$ & $95.45 \%$ \\
\hline
\end{tabular}

${ }^{*}$ The responses to the following Internet Use Frequency categories - Once a week or less, Once in 2-3 weeks, Once a month, Once in 3 months, Less than a few times a year, and Never - were combined.

\section{Table 11. Social media use frequency of respondents}

\begin{tabular}{|l|l|l|l|}
\hline \multicolumn{1}{|c|}{ Social Media Use Frequency } & \multicolumn{1}{c|}{ \% of Responses } & \multicolumn{1}{c|}{ Kuwait } \\
\hline 1 - Once a day or less* & $2.57 \%$ & $4.74 \%$ & $1.58 \%$ \\
\hline $2-30$ minutes a day & $17.07 \%$ & $23.28 \%$ & $14.23 \%$ \\
\hline $3-1-2$ hours a day & $28.05 \%$ & $35.78 \%$ & $24.51 \%$ \\
\hline $4-3$ hours a day or more & $52.30 \%$ & $36.21 \%$ & $59.68 \%$ \\
\hline
\end{tabular}

${ }^{*}$ The responses to the following Social Media Use Frequency categories - Once a day, Few times a week, Few times a month, Once a month or less, and Never - were combined.

Table 12. Primary source of health information of respondents

\begin{tabular}{|l|l|l|l|}
\hline \multicolumn{1}{|c|}{ Primary Source } & \multicolumn{1}{c|}{ \% of Responses } & \multicolumn{1}{c|}{ Kuwait } \\
\hline Books & $3.8 \%$ & $2.4 \%$ & $4.4 \%$ \\
\hline Doctors and Specialists & $43.9 \%$ & $43.9 \%$ & $43.9 \%$ \\
\hline Friends or Family & $8.2 \%$ & $19.4 \%$ & $3.1 \%$ \\
\hline Internet/Social Media & $66.9 \%$ & $72.0 \%$ & $64.6 \%$ \\
\hline Other & $2.7 \%$ & $3.5 \%$ & $2.3 \%$ \\
\hline
\end{tabular}


Table 13. Key estimation results of the main model

\begin{tabular}{|c|c|c|c|c|c|c|c|c|}
\hline \multirow{3}{*}{ Variables } & \multicolumn{4}{|c|}{ Knowledge Conversion } & \multicolumn{4}{|c|}{ Practice Decision } \\
\hline & \multicolumn{2}{|c|}{ (1) } & \multicolumn{2}{|c|}{ (2) } & \multicolumn{2}{|c|}{ (1) } & \multicolumn{2}{|c|}{ (2) } \\
\hline & KC_UMB & KC_STEM & KC_UMB & KC_STEM & D_UMB & D_STEM & D_UMB & D_STEM \\
\hline $\begin{array}{l}\text { Knowledge Conversion } \\
\text { (KC_STEM, KC_UMB) }\end{array}$ & & & & & $\begin{array}{l}0.546^{* * *} \\
(0.04)\end{array}$ & $\begin{array}{l}0.317 * * * \\
(0.04)\end{array}$ & $\begin{array}{l}0.544 * * * \\
(0.04)\end{array}$ & $\begin{array}{l}0.314 * * * \\
(0.04)\end{array}$ \\
\hline $\begin{array}{l}\text { Digital Source } \\
\text { (DIGITAL) }\end{array}$ & $\begin{array}{l}0.092 * \\
(0.05)\end{array}$ & $\begin{array}{l}0.103 * * \\
(0.05)\end{array}$ & & & $\begin{array}{l}-0.062 \\
(0.05)\end{array}$ & $\begin{array}{l}-0.011 \\
(0.06)\end{array}$ & & \\
\hline $\begin{array}{l}\text { Digital Knowledge } \\
\text { Verification (DIGITAL_ } \\
\text { VER) }\end{array}$ & & & $\begin{array}{l}0.210^{* * * *} \\
(0.06)\end{array}$ & $\begin{array}{l}0.193 * * * \\
(0.06)\end{array}$ & & & $\begin{array}{l}-0.035 \\
(0.07)\end{array}$ & $\begin{array}{l}0.015 \\
(0.07)\end{array}$ \\
\hline $\begin{array}{l}\text { Trust on Internet } \\
\text { (DIGITAL_TRUST) }\end{array}$ & $\begin{array}{l}-0.003 \\
(0.05)\end{array}$ & $\begin{array}{l}0.049 \\
(0.05)\end{array}$ & $\begin{array}{l}0.009 \\
(0.05)\end{array}$ & $\begin{array}{l}0.055 \\
(0.05)\end{array}$ & $\begin{array}{l}-0.037 \\
(0.06)\end{array}$ & $\begin{array}{l}-0.003 \\
(0.06)\end{array}$ & $\begin{array}{l}-0.036 \\
(0.06)\end{array}$ & $\begin{array}{l}-0.002 \\
(0.06)\end{array}$ \\
\hline $\begin{array}{l}\text { Digital Source } \mathrm{x} \text { Trust } \\
\text { (DIGITAL x DIGITAL_ } \\
\text { TRUST) }\end{array}$ & $\begin{array}{l}0.030 \\
(0.05)\end{array}$ & $\begin{array}{l}0.106^{* *} \\
(0.05)\end{array}$ & & & $\begin{array}{l}0.048 \\
(0.05)\end{array}$ & $\begin{array}{l}-0.044 \\
(0.06)\end{array}$ & & \\
\hline $\begin{array}{l}\text { Digital Verification } \mathrm{x} \\
\text { Trust (DIGITAL_VER x } \\
\text { DIGITAL_TRUST) }\end{array}$ & & & $\begin{array}{l}0.060 \\
(0.06)\end{array}$ & $\begin{array}{l}0.093^{*} \\
(0.06)\end{array}$ & & & $\begin{array}{l}0.041 \\
(0.06)\end{array}$ & $\begin{array}{l}-0.007 \\
(0.07)\end{array}$ \\
\hline $\begin{array}{l}\text { Culture } \\
\text { (CULTURE) }\end{array}$ & $\begin{array}{l}0.015 \\
(0.14)\end{array}$ & $\begin{array}{l}0.541 * * * \\
(0.14)\end{array}$ & $\begin{array}{l}0.055 \\
(0.14)\end{array}$ & $\begin{array}{l}0.667 * * * \\
(0.14)\end{array}$ & $\begin{array}{l}0.220 \\
(0.15)\end{array}$ & $\begin{array}{l}0.431 * * \\
(0.17)\end{array}$ & $\begin{array}{l}0.201 \\
(0.16)\end{array}$ & $\begin{array}{l}0.474 * * * \\
(0.17)\end{array}$ \\
\hline $\begin{array}{l}\text { Digital Knowledge } \\
\text { Evaluation } \\
\text { (DIGITAL_EVL) }\end{array}$ & & & $\begin{array}{l}0.47 \\
(0.06)\end{array}$ & $\begin{array}{l}-0.011 \\
(0.06)\end{array}$ & & & $\begin{array}{l}0.093 \\
(0.07)\end{array}$ & $\begin{array}{l}0.051 \\
(0.07)\end{array}$ \\
\hline $\begin{array}{l}\text { Frequency of Internet Use } \\
\text { (INT_FREQ) }\end{array}$ & $\begin{array}{l}0.050 \\
(0.07)\end{array}$ & $\begin{array}{l}-0.058 \\
(0.08)\end{array}$ & $\begin{array}{l}0.039 \\
(0.07)\end{array}$ & $\begin{array}{l}-0.059 \\
(0.07)\end{array}$ & $\begin{array}{l}-0.041 \\
(0.08)\end{array}$ & $\begin{array}{l}-0.148^{*} \\
(0.08)\end{array}$ & $\begin{array}{l}-0.044 \\
(0.11)\end{array}$ & $\begin{array}{l}-0.153^{*} \\
(0.08)\end{array}$ \\
\hline $\begin{array}{l}\text { Frequency of Social } \\
\text { Media Use } \\
\text { (SM_FREQ) }\end{array}$ & $\begin{array}{l}0.052 \\
(0.07)\end{array}$ & $\begin{array}{l}-0.63 \\
(0.08)\end{array}$ & $\begin{array}{l}0.046 \\
(0.07)\end{array}$ & $\begin{array}{l}-0.064 \\
(0.07)\end{array}$ & $\begin{array}{l}-0.035 \\
(0.08)\end{array}$ & $\begin{array}{l}-0.159^{*} \\
(0.08)\end{array}$ & $\begin{array}{l}-0.036 \\
(0.08)\end{array}$ & $\begin{array}{l}-0.163^{* *} \\
(0.08)\end{array}$ \\
\hline $\begin{array}{l}\text { Age Group } \\
\text { (AGE) }\end{array}$ & $\begin{array}{l}0.42 \\
(0.04)\end{array}$ & $\begin{array}{l}-0.027 \\
(0.04)\end{array}$ & $\begin{array}{l}0.44 \\
(0.04)\end{array}$ & $\begin{array}{l}-0.025 \\
(0.04)\end{array}$ & $\begin{array}{l}-0.58 \\
(0.04)\end{array}$ & $\begin{array}{l}0.010 \\
(0.04)\end{array}$ & $\begin{array}{l}-0.57 \\
(0.04)\end{array}$ & $\begin{array}{l}0.009 \\
(0.04)\end{array}$ \\
\hline $\begin{array}{l}\text { Gender } \\
\text { (GENDER) }\end{array}$ & $\begin{array}{l}0.106 \\
(0.11)\end{array}$ & $\begin{array}{l}-0.139 \\
(0.12)\end{array}$ & $\begin{array}{l}0.161 \\
(0.11)\end{array}$ & $\begin{array}{l}-0.101 \\
(0.12)\end{array}$ & $\begin{array}{l}0.004 \\
(0.12)\end{array}$ & $\begin{array}{l}0.095 \\
(0.14)\end{array}$ & $\begin{array}{l}0.015 \\
(0.13)\end{array}$ & $\begin{array}{l}0.106 \\
(0.14)\end{array}$ \\
\hline $\begin{array}{l}\text { Education Level } \\
\text { (EDUCATION) }\end{array}$ & $\begin{array}{l}0.168 * * * \\
(0.06)\end{array}$ & $\begin{array}{l}0.105^{*} \\
(0.06)\end{array}$ & $\begin{array}{l}0.159^{* * *} * \\
(0.06)\end{array}$ & $\begin{array}{l}0.101^{*} \\
(0.06)\end{array}$ & $\begin{array}{l}0.030 \\
(0.07)\end{array}$ & $\begin{array}{l}-0.010 \\
(0.07)\end{array}$ & $\begin{array}{l}0.029 \\
(0.07)\end{array}$ & $\begin{array}{l}-0.015 \\
(0.07)\end{array}$ \\
\hline $\begin{array}{l}\text { Household Income Level } \\
\text { (INCOME) }\end{array}$ & $\begin{array}{l}-0.060 \\
(0.50)\end{array}$ & $\begin{array}{l}0.053 \\
(0.05)\end{array}$ & $\begin{array}{l}-0.073 \\
(0.05)\end{array}$ & $\begin{array}{l}0.043 \\
(0.05)\end{array}$ & $\begin{array}{l}0.082 \\
(0.05)\end{array}$ & $\begin{array}{l}0.021 \\
(0.06)\end{array}$ & $\begin{array}{l}0.078 \\
(0.05)\end{array}$ & $\begin{array}{l}0.019 \\
(0.06)\end{array}$ \\
\hline R-squared/Chi-sq. & 0.08 & 0.02 & 0.10 & 0.03 & $227.08 * * *$ & & $228.43 * * *$ & \\
\hline Observations & 721 & & & & 707 & & & \\
\hline
\end{tabular}

Note: Robust standard errors in parentheses. Wald test was used to compare coefficients across two equations. Variable abbreviations in brackets represent dependent variables used in SUR. Variable abbreviations in parentheses represent independent variables. ${ }^{* * *} p<0.01,{ }^{* *} p<0.05,{ }^{*} p<0.1$. 
Table 14. Robustness checks

\begin{tabular}{|c|c|c|c|c|}
\hline \multirow{2}{*}{ Variables } & \multicolumn{2}{|c|}{$\begin{array}{l}\text { Knowledge } \\
\text { Conversion }\end{array}$} & \multicolumn{2}{|c|}{$\begin{array}{l}\text { Practice } \\
\text { Decision }\end{array}$} \\
\hline & KC_UMB & KC_STEM & D_UMB & D_STEM \\
\hline $\begin{array}{l}\text { Practice Knowledge } \\
\text { (PK_STEM,PK_UMB) }\end{array}$ & & & $\begin{array}{l}1.633 * * * \\
(0.11)\end{array}$ & $\begin{array}{l}0.875 * * * \\
(0.08)\end{array}$ \\
\hline $\begin{array}{l}\text { Digital Knowledge Verification } \\
\text { (DIGITAL_VER) }\end{array}$ & $\begin{array}{l}0.107 * * \\
(0.04)\end{array}$ & $\begin{array}{l}0.091 * * \\
(0.04)\end{array}$ & $\begin{array}{l}-0.061 \\
(0.09)\end{array}$ & $\begin{array}{l}-0.027 \\
(0.08)\end{array}$ \\
\hline $\begin{array}{l}\text { Trust on Internet } \\
\text { (TRUST) }\end{array}$ & $\begin{array}{l}0.003 \\
(0.04)\end{array}$ & $\begin{array}{l}0.048 \\
(0.04)\end{array}$ & $\begin{array}{l}-0.019 \\
(0.08)\end{array}$ & $\begin{array}{l}-0.049 \\
(0.07)\end{array}$ \\
\hline $\begin{array}{l}\text { Digital Verification x Trust } \\
\text { (DIGITAL_VER x TRUST) }\end{array}$ & $\begin{array}{l}0.079 * * \\
(0.04)\end{array}$ & $\begin{array}{l}0.090^{* *} \\
(0.04)\end{array}$ & $\begin{array}{l}-0.043 \\
(0.08)\end{array}$ & $\begin{array}{l}-0.056 \\
(0.08)\end{array}$ \\
\hline $\begin{array}{l}\text { Culture } \\
\text { (CULTURE) }\end{array}$ & $\begin{array}{l}0.077 \\
(0.10)\end{array}$ & $\begin{array}{l}0.310^{* * * *} \\
(0.10)\end{array}$ & $\begin{array}{l}0.234 \\
(0.22)\end{array}$ & $\begin{array}{l}0.746^{* * * *} \\
(0.20)\end{array}$ \\
\hline $\begin{array}{l}\text { Digital Knowledge Evaluation } \\
\text { (DIGITAL_EVL) }\end{array}$ & $\begin{array}{l}0.057 \\
(0.04)\end{array}$ & $\begin{array}{l}0.050 \\
(0.04)\end{array}$ & $\begin{array}{l}0.079 \\
(0.09)\end{array}$ & $\begin{array}{l}0.047 \\
(0.08)\end{array}$ \\
\hline $\begin{array}{l}\text { Frequency of Internet Use } \\
\text { (INT_FREQ) }\end{array}$ & $\begin{array}{l}0.024 \\
(0.05)\end{array}$ & $\begin{array}{l}-0.053 \\
(0.05)\end{array}$ & $\begin{array}{l}-0.084 \\
(0.11)\end{array}$ & $\begin{array}{l}-0.183 * * \\
(0.09)\end{array}$ \\
\hline $\begin{array}{l}\text { Frequency of Social Media Use } \\
\text { (SM_FREQ) }\end{array}$ & $\begin{array}{l}0.029 \\
(0.05)\end{array}$ & $\begin{array}{l}-0.054 \\
(0.05)\end{array}$ & $\begin{array}{l}-0.064 \\
(0.11)\end{array}$ & $\begin{array}{l}-0.166^{*} \\
(0.09)\end{array}$ \\
\hline $\begin{array}{l}\text { Age Group } \\
\text { (AGE) }\end{array}$ & $\begin{array}{l}0.014 \\
(0.03)\end{array}$ & $\begin{array}{l}-0.031 \\
(0.03)\end{array}$ & $\begin{array}{l}-0.068 \\
(0.05)\end{array}$ & $\begin{array}{l}0.018 \\
(0.05)\end{array}$ \\
\hline $\begin{array}{l}\text { Gender } \\
\text { (GENDER) }\end{array}$ & $\begin{array}{l}0.023 \\
(0.08)\end{array}$ & $\begin{array}{l}-0.077 \\
(0.08)\end{array}$ & $\begin{array}{l}0.057 \\
(0.17)\end{array}$ & $\begin{array}{l}0.185 \\
(0.15)\end{array}$ \\
\hline $\begin{array}{l}\text { Education Level } \\
\text { (EDUCATION) }\end{array}$ & $\begin{array}{l}0.093 * * \\
(0.04)\end{array}$ & $\begin{array}{l}0.111 * * * \\
(0.04)\end{array}$ & $\begin{array}{l}0.072 \\
(0.09)\end{array}$ & $\begin{array}{l}-0.093 \\
(0.08)\end{array}$ \\
\hline $\begin{array}{l}\text { Household Income Level } \\
\text { (INCOME) }\end{array}$ & $\begin{array}{l}0.013 \\
(0.03)\end{array}$ & $\begin{array}{l}0.041 \\
(0.03)\end{array}$ & $\begin{array}{l}-0.048 \\
(0.07)\end{array}$ & $\begin{array}{l}0.042 \\
(0.06)\end{array}$ \\
\hline R-squared/Chi-sq. & 0.06 & 0.04 & \multicolumn{2}{|l|}{$331.80 * * *$} \\
\hline Observations & \multicolumn{2}{|l|}{721} & \multicolumn{2}{|l|}{707} \\
\hline
\end{tabular}

${ }^{*} p<0.10,{ }^{* *} p<0.05,{ }^{* * *} p^{*} 0.01 ;+$ Variables in brackets represent equations estimated.

Abrar Al-Hasan is an Assistant Professor of Information Systems at Kuwait University. Her research interests include Social Media and Social Networks, Online Markets and Digital Innovations, Crowdsourcing and Open Innovations, and Economics of Information Systems. She holds an MBA and a PhD in MIS from University of Maryland, College Park, and a BSc in Computer Engineering from Kuwait University.

Jiban Khuntia is Assistant Professor and Ph.D. Program Director at the Business School of University of Colorado Denver. His research interests are in the areas of health information technology, digital service innovation, and sustainability. His work has appeared in premier journals like Production and Operations Management, Journal of Management Information Systems, and Decision Support Systems. He holds a PhD from University of Maryland, College Park. Prior to PhD, he had a decade long experience in industry. He has also consulted to many government and private enterprises.

Dobin Yim received his PhD in Management Information Systems from the University of Maryland, College Park. He is currently an Assistant Professor of Information Systems in the Information Systems, Law, and Operations (ISLO) Department at the Sellinger School of Business, Loyola University Maryland. He examines the social impact of information technology in healthcare, media management, and environmental sustainability. 